\title{
Plankton biomass and larval fish abundance prior to and during the El Niño period of 1997-1998 along the central Pacific coast of México
}

\author{
C. Franco-Gordo ${ }^{\text {a,b,*,1 }}$, E. Godínez-Domínguez ${ }^{\text {a,b,1 }}$, A.E. Filonov ${ }^{\text {c }}$, \\ I.E. Tereshchenko ${ }^{c}$, J. Freire ${ }^{b, 1}$ \\ ${ }^{a}$ Centro de Ecología Costera, Universidad de Guadalajara, 48980, México \\ b Departamento de Bioloxía Animal, Bioloxía Vexetal e Ecoloxía, Universidade da Coruña, Campus da Zapateira s/n. A Coruña, \\ 15071, Spain \\ c Departamento de Física, CUCEI, Universidad de Guadalajara, México
}

Received 21 January 2004; received in revised form 30 September 2004; accepted 28 October 2004

Available online 25 December 2004

\begin{abstract}
The temporal and spatial distributions of zooplankton biomass and larval fish recorded during 27 months (December 1995-December 1998) off the Pacific coast of central México are analyzed. A total of 316 samples were obtained by surface (from 40-68 to $0 \mathrm{~m}$ ) oblique hauls at 12 sampling sites using a Bongo net. Two well-defined periods were observed: a pre-ENSO period (December 1995-march 1997) and an ENSO event (July 1997-September 1998) characterized by impoverishment of the pelagic habitat. The highest biomass concentrations occurred at coastal stations during the pre-ENSO period. During the El Niño period no spatial patterns were found in coastal waters. The months with highest biomass were those in which the lowest sea surface temperature (SST) occurred (January-May), and this pattern was also observed during the ENSO period. A typical, although attenuated, seasonal environmental pattern with enhanced phytoplankton (diatoms and dinoflagellates) was prevalent during the El Niño event in nearshore waters. During the El Niño period the phytoplankton was mainly small diatoms (microphytoplankton), while dinoflagellates were practically absent. The most parsimonious generalized linear models explaining spatial and temporal distribution of larval fish species included the ENSO index (MEI), upwelling index (UI) and distance to the coast. The environmental variability defined on an interannual time-scale by the ENSO event and the seasonal hydroclimatic pattern defined by the UI (intra-annualscale) controlled the ecosystem productivity patterns. The small-scale distribution patterns (defined by a cross-shore gradient) of plankton were related to the hydroclimatic seasonality and modulated by interannual anomalies.
\end{abstract}

(c) 2004 Elsevier Ltd. All rights reserved.

\footnotetext{
* Corresponding author.

E-mail address: cfranco@costera.melaque.udg.mx (C. Franco-Gordo).

${ }^{1}$ Tel.: +34 981 167000x2204; fax: +34 981167065 .
} 
Keywords: Mexican central Pacific; Inshore phytoplankton; Zooplankton; Larval fish assemblages; El Niño

\section{Introduction}

The ENSO phenomenon is an irregular fluctuation that involves the entire tropical Pacific Ocean and global atmosphere (Philander, 1999). ENSO itself consists of an unstable interaction between sea surface temperature (SST) and the atmospheric pressure field. It results in variations in winds, rainfall, thermocline depth, circulation, and ultimately in biological productivity, modifying the feeding and reproduction of fish, birds and mammals (Fiedler, 2002). The 1997-1998 El Niño was the strongest of the 20th century (Kerr, 1998; McPhaden, 1999), and its consequences are still being surveyed.

Knowledge about the physical and climatological mechanisms of El Niño and La Niña events has increased recently, and the environmental variability in the Pacific Ocean begins to be well understood (see Bograd \& Lynn, 2001; Chavez et al., 1999, 2002; Fedorov \& Philander, 2000; Fiedler, 2002; Lehodey, 2001; Philander, 1998) at global and regional scales, while the knowledge about ecological impacts in marine habitats remains partial and spatially fragmented. The magnitude, and even the sign, of the response differs among regions. The strongest and the most rapid effects appear at lower trophic levels, although responses can be observed at higher levels (Fulton \& LeBrasseur, 1985; Mullin, 1995). The physical-biological coupling has been reported as mainly an early effect of El Niño, represented by a decrease of nutrient availability (Bograd \& Lynn, 2001; Fiedler, 1984), and a subsequent decrease of primary and secondary production (Chavez et al., 2002; McGowan, 1985). However, variations from this kind of response are found along the eastern North Pacific (Fiedler, 2002). Zooplankton biomass decreased off Southern California (Roemmich \& McGowan, 1995) and did not change substantially off Baja California (Lavaniegos, Gómez-Gutierrez, Lara-Lara, \& Hernández-Vázquez, 1998).

Changes in zooplankton biomass are often secondary to changes in species composition. These large and widespread changes affect planktonic communities at multiple trophic levels (Ainley, Syderman, \& Norton, 1995; Brodeur, Francis, \& Pearcy, 1992; Chelton, Bernal, \& McGowan, 1982; Graybill \& Hodder, 1985; Miller, Batchelder, Brodeur, \& Johnson, 1985; Mysak, 1986; Pearcy \& Schoener, 1987). Because most of the animals that inhabit the marine environment have a planktonic larval phase, it is expected that changes in planktonic communities associated with ENSO events significantly affect recruitment rates to adult populations. However, the species-specific response to such climatological perturbations is quite variable. In some cases, recruitment is higher than normal during the El Niño period (Connolly \& Roughgarden, 1999; Ebert, Schroeter, Dixon, \& Kalvass, 1994; Paine, 1986; Roughgarden, Gaines, \& Possingham, 1988), but in other cases, recruitment is below levels seen in prior or subsequent years (Ebert et al., 1994; Tegner \& Dayton, 1987).

During El Niño, local upwelling-favorable winds in the eastern tropical Pacific are maintained and even intensified (Enfield, 1981), although the coastal upwelling transports low-nutrient waters due to a deepening of the nutricline remotely forced by Kelvin waves (Barber \& Chavez, 1983). Some signals of typical seasonality are evidenced mainly in nearshore waters during El Niño events (Chavez et al., 2002), and their implications in the recovery of the previous ecological state have not been well understood. In the North American Pacific, the nutrient levels and productivity of coastal waters suffer a dramatic reduction during El Niño events, the oceanic ecosystem impinges on the shore (Chavez et al., 2002), and the local communities are dominated by tropical or southern species (Lavaniegos, Jiménez-Perez, \& Gaxiola-Castro, 2002; Mackas \& Galbraith, 2002; Marinovic, Croll, Gong, Benson, \& Chavez, 2002). However the narrow nearshore fringe conserves a relatively high productivity (Barber \& Chavez, 1983; Chavez et al., 2002; Kudela \& 
Chávez, 2000), and the coastal processes could be determinant for recruitment to local populations (Connolly \& Roughgarden, 1999; Marinovic et al., 2002).

The predominant surface current patterns in the central Mexican Pacific, described by Wyrtki (1965), determine the hydroclimatic seasonality consisting of three phases: the first is influenced by the California Current, and it is characterized by a cold water mass from January to May; the second (July-November) is influenced by the North Equatorial Countercurrent and characterized by a tropical water mass (Badan, 1997; Filonov, Tereshchenko, Monzón, González-Ruelas, \& Godínez-Domínguez, 2000); the third is determined by the transitions between the previous phases, neither one dominating. The dynamic response of the coastal ecosystem to these seasonal patterns has been studied with respect to zooplankton biomass, larval fish abundance and diversity of ichthyoplankton by Franco-Gordo, Godínez-Domínguez, and Suárez-Morales (2001a, 2001b, 2002, 2003). The macroinvertebrate assemblages and diversity (Godínez-Domínguez \& Freire, 2003; Godínez-Domínguez, Freire, Franco-Gordo, \& González-Sansón, in review), coastal fish assemblages (Godínez-DomíRojo-Vázquez, Rojo-Vázquez, Piña-Galván, \& Aguilar-Palomino, 2000) and coastal water mass dynamics (Filonov et al., 2000) respond to the same seasonal patterns.

Although the El Niño is a global-scale process, with particularly dramatic oceanographic effects in the tropical Pacific (Chavez et al., 2002), most of the surveys along the North American Pacific coast that evaluated oceanographic and ecological effects have been located in temperate or subartic latitudes $\left(30-50^{\circ} \mathrm{N}\right)$. With the exception of some papers about equatorial zones, the effects of ENSO events along the tropical Pacific coasts remain unknown. In Mexican waters, the west coast of Baja California and Gulf of California have been relatively well studied; however, there is a big gap of information southward from Mazatlán to the Gulf of Tehuantepec. In this paper, we describe the oceanographic variability during the 1997-1998 El Niño event in Mexican tropical coastal waters $\left(19-20^{\circ} \mathrm{N}\right)$, and the environmental-biological coupling. Our results will show the prevalence of typical intra-annual seasonality of production processes during an El Niño event in nearshore waters. Finally, models are shown that identify some of the key factors affecting the distribution and abundance of the larval fish assemblage in coastal waters prior and during the ENSO event.

\section{Methods}

\subsection{Study area}

The surveyed area comprised a fringe along the continental shelf off the coasts of Jalisco and Colima (Fig. 1), the central portion of the Mexican Pacific located between Punta Farallón, in Jalisco $\left(19^{\circ} 19^{\prime} 77^{\prime \prime} \mathrm{N}, 105^{\circ} 00^{\prime} 28^{\prime \prime} \mathrm{W}\right)$, and Cuyutlán, Colima $\left(18^{\circ} 58^{\prime} 24^{\prime \prime} \mathrm{N}, 104^{\circ} 13^{\prime} 51^{\prime \prime} \mathrm{W}\right)$.

\subsection{Physical oceanography sampling}

Internal tides are known to cause significant vertical variations in all hydrophysical parameters over the continental shelf. The spatial slopes of the dynamic heights on the continental shelf can be up to one order of magnitude greater than the normal values for areas of the open ocean. The internal tides may cause the temperature and salinity measurements over the continental shelf to provide different results with respect to geostrophic currents, depending on the tidal phase in which they were taken; Filonov, Monzón, and Tereshchenko (1996) proposed a method to conduct a fast oceanographic survey with an undulating CTD over a grid of frequent stations that can be averaged to remove the influence of internal waves.

The oceanographic surveys covered a polygonal area (Fig. 1) on board the research vessel BIP-V and were performed with a towed CTD profiler SBE-19, which was placed in a streamlined box. At the full 


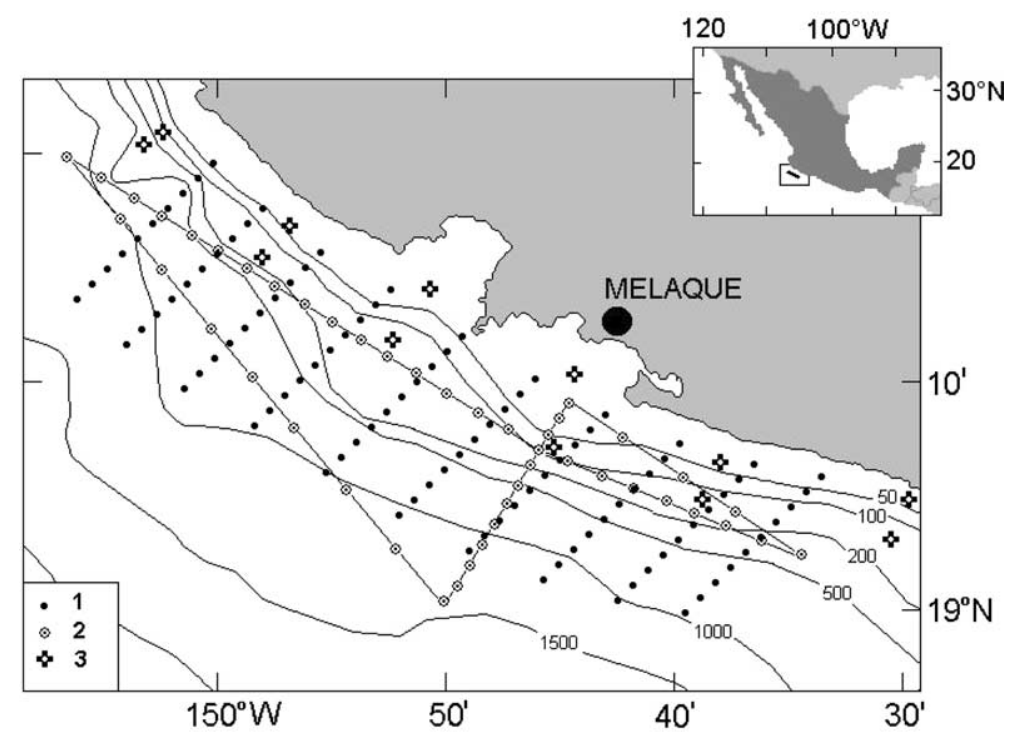

Fig. 1. Study area. (a) The cruise track corresponding to 1996-1997 surveys; lines with arrowheads are the cruise track corresponding to 1998 surveys. (b) The sites were plankton samples and CTD profiles were taken (December 1995-December 1998).

vessel speed of about 6 knots, the profiler moved near the surface. For measuring purposes, the vessel, while keeping its speed unchanged, made a couple of circles to help the profiler sink at a speed of as much as $1 \mathrm{~m} / \mathrm{s}$ to a depth defined by the length of the towing cable; then, the vessel moved to the next measurement site (Filonov et al., 1996). The survey coordinates were recorded with the help of a Global Positioning System (GPS) receiver. The sample rate for depth, temperature, and salinity was twice per second (hence with a depth step of $0.5 \mathrm{~m}$ ); then, the measured data were smoothed over depth using a cosine filter with a half width of $2 \mathrm{~m}$ and recorded with a step of $1 \mathrm{~min}$.

Previous measurements in the area had shown that seasonal cycles occur only in the upper $120 \mathrm{~m}$ layer (Filonov et al., 2000), so surveys were made to $150 \mathrm{~m}$ depth. Each survey consisted of 10 sections $1.5 \mathrm{~km}$ apart and perpendicular to the coastline. A typical survey covered $50 \times 15 \mathrm{~km}$ (Fig. 1), yielding about 100 vertical profiles of temperature and salinity. In January 1998, the sampling method was changed to a crossshaped $(80 \times 30 \mathrm{~km}$ track). Usually, the surveys were done on the 15 th of each month. A total of 29 surveys were conducted between January 1996 and June 1998, yielding 2374 temperature and salinity profiles (Filonov \& Tereshchenko, 2000).

The temperature and salinity anomalies caused by the El Niño event were compared against the monthly sea surface temperature (SST) anomalies in the equatorial part of the Pacific, region $\mathrm{B}\left(4^{\circ} \mathrm{N}-4^{\circ} \mathrm{S}, 90^{\circ} \mathrm{W}-\right.$ $150^{\circ} \mathrm{W}$ ) (Monthly Ocean Report, 1998). For this purpose, the vertical integrations of the $T$ and $S$, from 0 to $150 \mathrm{~m}$ depth, were taken for each month, and the active layer of heat storage per unit surface area was calculated following Mamayev (1975):

$$
S=\frac{1}{M} \sum_{i=1}^{N} \sum_{j=1}^{M} \rho_{i j} C_{\mathrm{p}_{i j}} T_{i j} \Delta z,
$$

where $M$ is the number of vertical soundings in a survey, $N$ is the number of $1-m$ depth increments, $\rho$ is water density, $C_{\mathrm{p}}$ is specific heat content, $T$ is water temperature. 


\subsection{Zooplankton sampling}

The area was surveyed using a 12-station plan (Fig. 1) on board the BIP-V oceanographic vessel exclusively over the continental shelf. Zooplankton samplings were carried out monthly at night (20:00-07:00) from December 1995 through December 1998 (27 months). No samplings were made in some months due to adverse weather. Zooplankton tows were performed following Smith and Richardson (1977). Samples were collected with a Bongo net $(0.505 \mathrm{~mm}$ mesh) hauled obliquely from a depth of $42-86 \mathrm{~m}$, which implied a sampling range of $60-90 \%$ of the water column in the surveyed area. A digital flowmeter was adapted to the net mouth in order to estimate the volume of water filtered. Previous to each tow, a profile of temperature and salinity was recorded using a SBE-19 CTD profiler. Samples were fixed and preserved in a 4\% formalin solution buffered with sodium borate (Griffiths, Fleminger, \& Vannucci, 1976). Samples were immediately processed to obtain the zooplankton biomass in order to avoid volume changes associated with long-term preservation. Samples were processed according to the displacement volume method (Beers, 1976). Organisms measuring over $3 \mathrm{~cm}$ length were excluded from the samples; gelatinous zooplankters below this size were included in the biomass estimations. Estimated biomass values are reported as $\mathrm{cm}^{3}$ per $1000 \mathrm{~m}^{3}$ of filtered water. Fish larvae were sorted and abundance data were standardized to number of larvae per $10 \mathrm{~m}^{2}$ (Smith \& Richardson, 1977). Two-way ANOVAs were carried out to determine differences in larval fish abundance and zooplankton biomass among months of the year and inshore vs. offshore. Separate analyses were carried out for the pre-El Niño and El Niño period.

\subsection{Phytoplankton sampling}

During 1998, samples of water were taken from 0 and $25 \mathrm{~m}$ depth before the zooplankton tows using Niskin bottles (5 1). Diatom and dinoflagellate abundances were quantified following the Utermöhl procedure (Hasle, 1978). Two-way ANOVA tests were employed to determine the effects on abundances of diatoms and dinoflagellates of sampling months and distance inshore vs. offshore.

\subsection{Modeling spatial and temporal variability of the larval fish assemblage}

\subsubsection{Selection of environmental variables}

The following environmental variables were used:

- Inshore and offshore sea surface temperature (SST) and salinity.

- The Multivariate ENSO Index MEI (Wolter \& Timlin, 1993, 1998) as an indicator of El Niño/La Niña conditions in the tropical Pacific. The MEI is based on six highly correlated observed variables in the tropical Pacific: SST, atmospheric sea level, pressure (SLP), surface winds, zonal and meridional surface air temperature and total cloudiness. (Details on the computation of the MEI are available at: www.cdc.noaa.gov/ kew/MEI/mei.htlm).

- The upwelling index UI (at $21^{\circ} \mathrm{N}$, available at www.pfeg.noaa.gov).

We consider that these variables integrate simple and complex, short and long term, local and wide scale environmental variability, and could define an adequate environmental framework for local ecological processes. A principal component analysis (PCA) was employed to determine the similarity among variables, to reduce their number for posterior generalized linear model (GLM) analyses and to reduce the dimensionality of resultant models. Because UI and MEI are estimated for different geographical areas (MEI is a complex index based on equatorial indicators, while UI is defined by environmental variability $1^{\circ}$ to the 
north from the study area), a cross-correlation analysis of MEI, UI and local environmental variables was performed to determine the possible lag of the signals of MEI and UI in relation to local environmental variability.

\subsubsection{Models of larval fish abundance}

Generalized linear models (GLM) were used to analyze the spatial and temporal patterns in the variability of larval fish abundance. The following independent variables were included: environmental variables (selection criteria were explained previously), a linear temporal trend (number of months from December 1995), distance from the coast (inshore vs. offshore), and local hydroclimatic seasonality (tropical, transition and subtropical-temperate seasons). These variables define the most significant components of spatial, intra-annual and interannual variability in the coastal ecosystem. Model selection was based in the best subset procedure using the Akaike information criterion (AIC), and a normal log link was assumed.

\section{Results}

\subsection{Vertical temperature and salinity profiles}

The water mass in the Polygon area belongs to the Eastern Tropical type of Pacific Ocean waters. This area is influenced by a complex system of currents. In the winter months, some parts of the California Current and a surface current, which flows out of the Gulf of California, can reach the area. In summer, the currents caused by the penetration of the North Equatorial Countercurrent, dominate in the region (Wyrtki, 1965).

A distinct change in the hydrological pattern of the Polygon area caused by El Niño became clear in July 1997. A weakening of trade winds resulted in a displacement of the Subsurface Equatorial Water toward the Mexican coast. This water mass has relatively high temperature and low salinity. Its TS-characteristics are identical to those of the Pacific tropical surface water (PTSW). Eventually, this water mass drove the local water out of the upper layer. The vertical distribution of temperature and salinity in the upper 150-m layer (Fig. 2) changed most during June-December 1997. It was this change that made the major contribution to the total difference between the 1996 and 1997 distributions. During July-August 1997, the slope of the thermocline was much less steep, and the increase in salinity from 34 psu on the surface to 34.7 psu at a $150-\mathrm{m}$ level, was almost linear.

In September 1997, the vertical temperature profile became noticeably bowed downward (Fig. 2), which suggests the formation or intrusion of the PTSW homogenous layer. The layer grew steadily throughout the entire fall period, and in December 1997 its thickness had reached $70 \mathrm{~m}$. The corresponding water temperature was $28.5^{\circ} \mathrm{C}$. At the same time, salinity had dropped to $33.5 \mathrm{pss}$ at the surface, while in the homogeneous layer it had increased to 34 pss.

The impact of El Niño reached its peak in January 1998. At that time, PTSW filled the entire upper 80-m layer at $27.5^{\circ} \mathrm{C}$ and salinity less than 34 pss. For comparison, in January 1996, the surface temperature was $25.5^{\circ} \mathrm{C}$ and the top of the thermocline was at $25 \mathrm{~m}$. Even at $90 \mathrm{~m}$, the temperature was $15^{\circ} \mathrm{C}$ and salinity was 35 pss (Fig. 3, presents mean T,S-curves for January 1996 and January 1998). During the El Niño year, an 80-m subsurface layer was filled with PTSW, the 80-96 m layer was filled with the Pacific equatorial superficial water (PESW), and everything below that layer was filled with the Pacific subtropical subsuperficial water (PStSsW).

In February 1998, the homogeneous layer was less than $40 \mathrm{~m}$ thick, its temperature was $25^{\circ} \mathrm{C}$ and salinity was higher than 34 pss. Significant departures (up to $4-5{ }^{\circ} \mathrm{C}$ ) from the pre-El Niño temperature profile were still observed in March 1998, but in general, the temperature was close to that in March 1996. The vertical distribution of salinity in that month was like that during the previous year. By May 1998, 
(a) Temperature, ${ }^{\circ} \mathrm{C}$
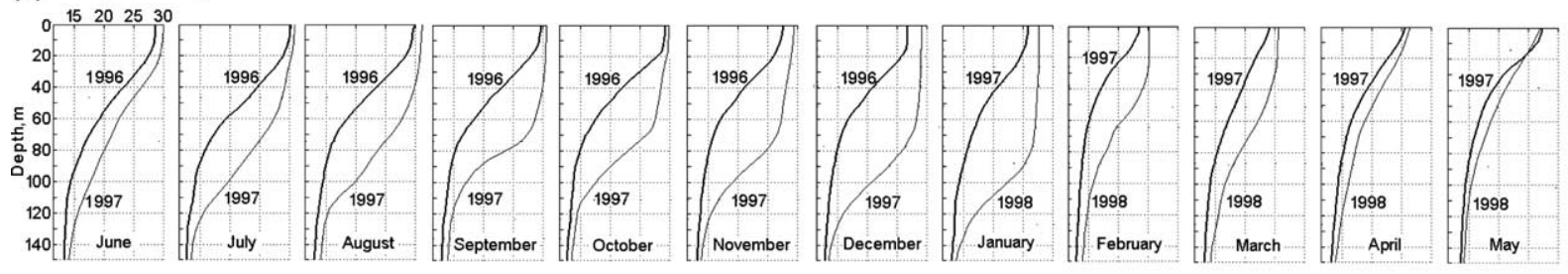

\section{(b) Salinity, psu}
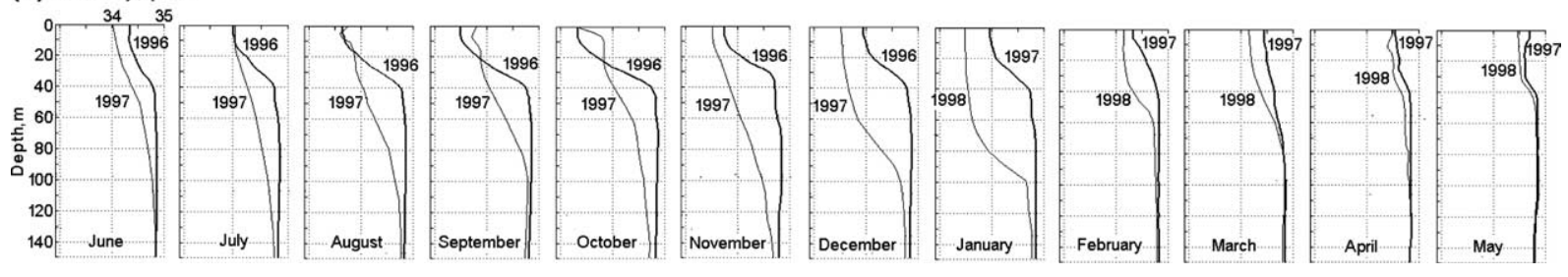

Fig. 2. Mean (a) temperature and (b) salinity profiles based on monthly surveys for the period June 1996-June 1998.

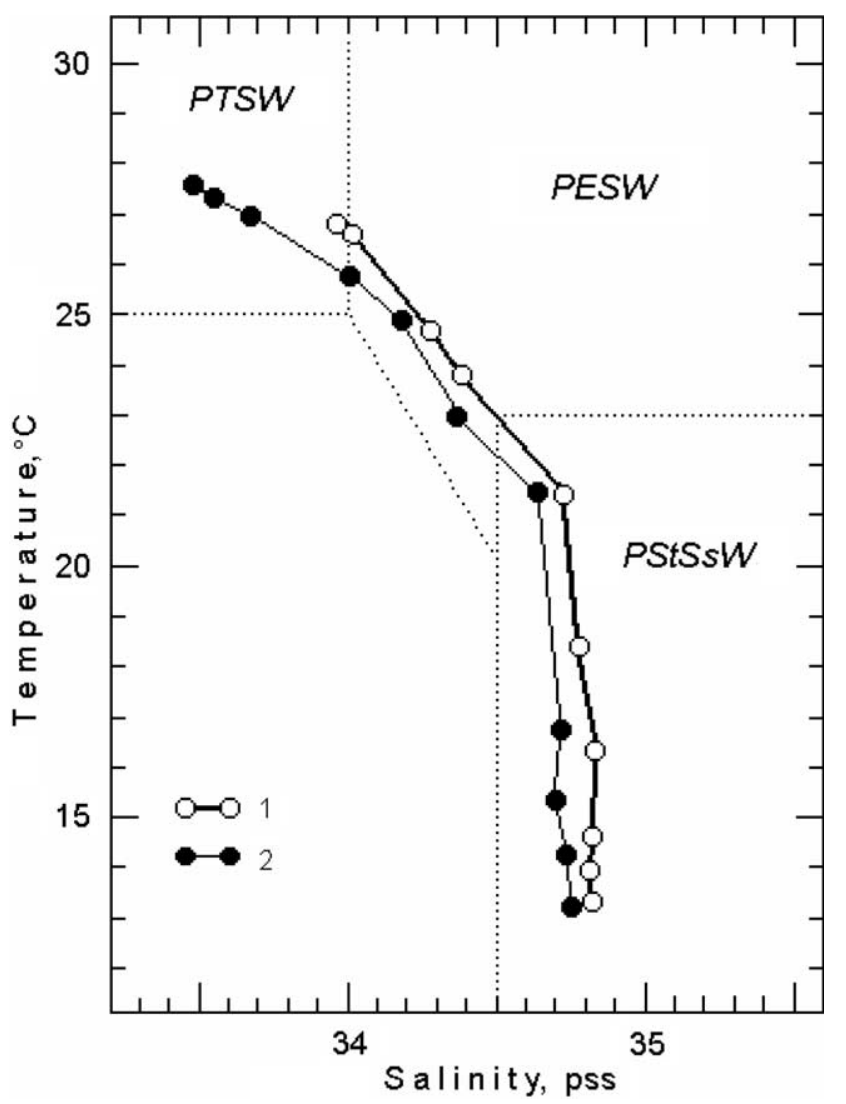

Fig. 3. Mean TS curves for (1) January 1996 and (2) January 1998. The dotted lines indicate the boundaries between the Pacific tropical surface water (PTSW), Pacific equatorial superficial water (PESW) and Pacific subtropical subsuperficial water (PStSsW). 
the evolution of El Niño had progressed to an greater extent, producing $T S$-characteristics barely different from those in May 1996. Only in the upper 60-m layer was the salinity $0.2-0.3$ pss below the values observed in the previous year. Therefore, the results demonstrate that in May 1998, the thermodynamic cycle caused by the 1997-1998 El Niño event was over.

\subsection{The evolution of the 1997-1998 El Niño event and heat storage}

During the 1997-1998 El Niño event, the heat storage rate, the rise in temperature and the drop in salinity within the active layer agreed well with SST anomalies time series in region B. In January 1998, the temperature was $7.6^{\circ} \mathrm{C}$ higher and salinity was 0.5 pss lower than in January 1996 . Over the same period, the heat storage of the oceanic active layer had increased from 10.1 to $15.3 \mathrm{GJ} / \mathrm{m}^{2}$. During all of 1996 , the sea surface temperature anomalies in region B were close to zero (Fig. 4). Beginning in 1997, their values became positive and continued to increase until December, when they peaked at $+4.5^{\circ} \mathrm{C}$.Then, from January 1998 they rapidly decreased and almost decayed to zero by June of 1998. The El Niño had the strongest impact on the Mexican coast within a month after the El Niño Index reached its peak in region B (Monthly Ocean Report, 1998).

\subsection{Environmental-biological coupling. Relation between environmental variability and zooplankton biomass and larval fish abundance}

Two well-defined periods were observed in the monthly zooplankton biomass and larval fish abundance time series; first, a pre-ENSO period (December 1995-March 1997), and second, the ENSO event, defined by an impoverishment of the pelagic habitat that started suddenly in the summer of 1997 (Fig. 5). During
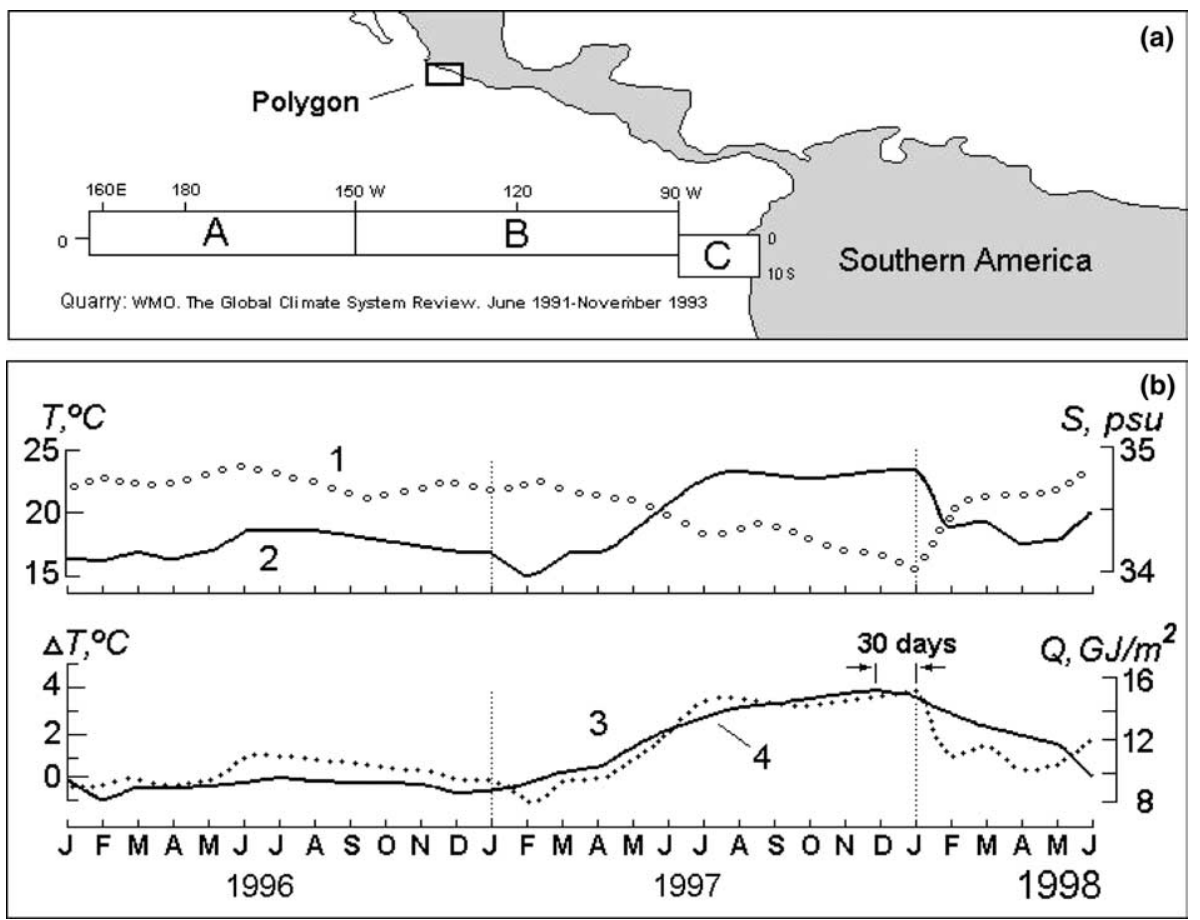

Fig. 4. Temperature (1), salinity (2) and heat storage (3) variations in the $0-150-\mathrm{m}$ active layer, and monthly sea surface temperature anomalies (SST) in the equatorial region $\mathrm{B}\left(4^{\circ} \mathrm{N}-4^{\circ} \mathrm{S} ; 90^{\circ} \mathrm{W}-150^{\circ} \mathrm{W}\right)$ of the Pacific Ocean in 1996-1998 (4). 


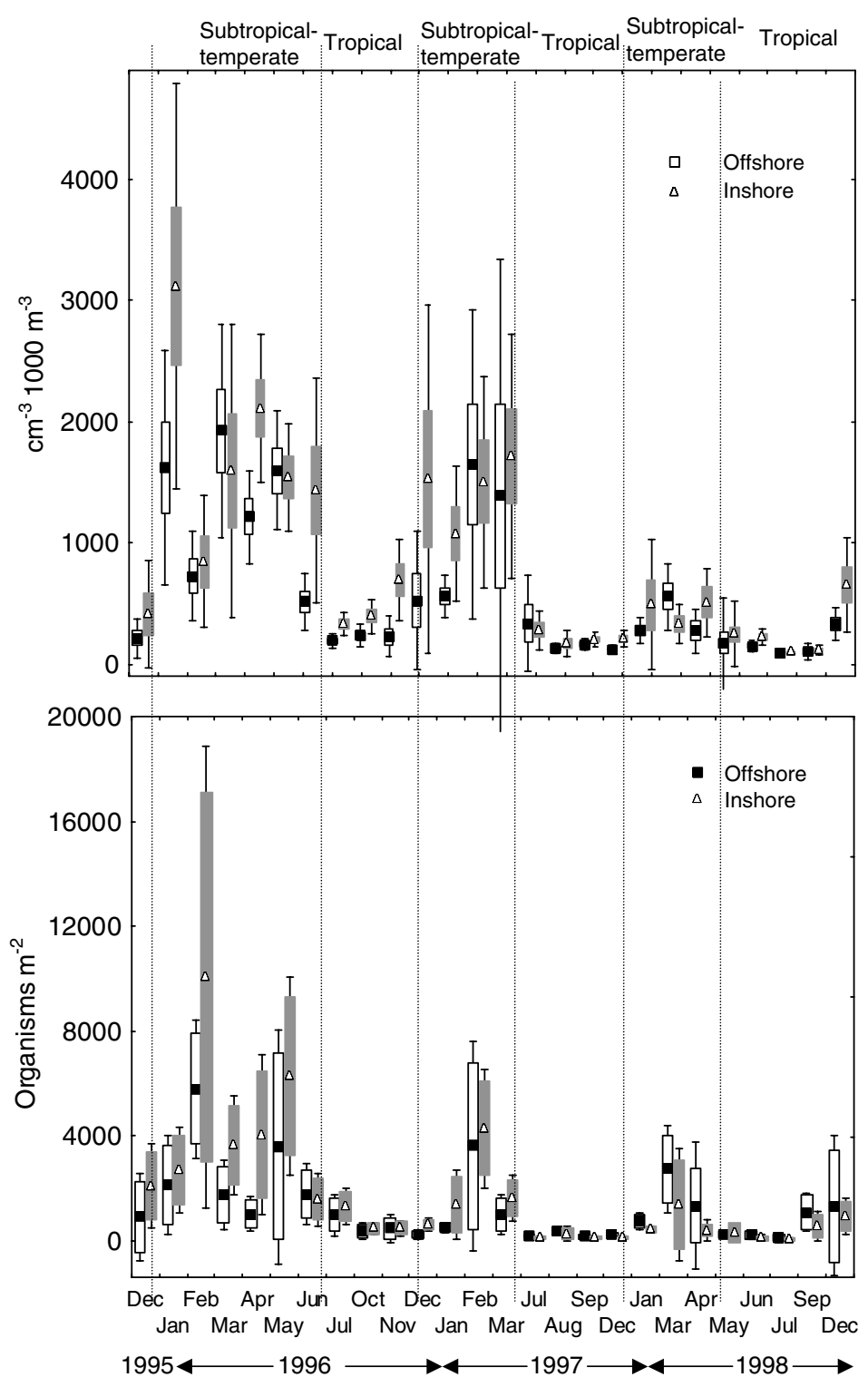

Fig. 5. Monthly variability of the zooplankton biomass and larval fish abundance during and prior the El Niño 1997-1998 event. Mean offshore and inshore values are represented by empty boxes and shaded boxes respectively. Vertical lines represent the $95 \%$ confidence interval and boxes one standard error.

the pre-El Niño period, there were significant differences in larval fish abundance and zooplankton biomass among months $(p<0.001$; Table 1$)$, and the highest abundance and biomass concentrations occurred at inshore stations $(p<0.003)$. During the El Niño period, monthly differences were again observed in both abundance and biomass $(p<0.001)$, but no significant difference was found between offshore and inshore stations $(p>0.072)$. The months with highest biomass were those in which the lowest SST occurred (January-May), and this pattern persisted during the anomalously warm El Niño 1997-1998 period. This was 
Table 1

Results of GLM ANOVAs comparing larval fish abundance and distance from the coast during the pre-EI Niño and El Niño 19971998 period

\begin{tabular}{|c|c|c|c|c|c|c|c|c|c|c|c|c|}
\hline & \multicolumn{6}{|c|}{ Larval fish abundance } & \multicolumn{6}{|c|}{ Zooplankton biomass } \\
\hline & \multicolumn{3}{|c|}{ pre-EI Niño period } & \multicolumn{3}{|c|}{ EI Niño period } & \multicolumn{3}{|c|}{ pre-EI Niño period } & \multicolumn{3}{|c|}{ EI Niño period } \\
\hline & $d f$ & $F$ & $p$ & $d f$ & $F$ & $p$ & $d f$ & $F$ & $p$ & $d f$ & $F$ & $p$ \\
\hline Intercept & 1 & 143.64 & $<0.001$ & 1 & 38.42 & $<0.001$ & 1 & 337.44 & $<0.001$ & 1 & 174.72 & $<0.001$ \\
\hline Month & 13 & 8.51 & $<0.001$ & 11 & 3.63 & $<0.001$ & 13 & 8.49 & $<0.001$ & 11 & 4.50 & $<0.001$ \\
\hline Distance & 1 & 9.23 & 0.003 & 1 & 3.29 & 0.072 & 1 & 11.59 & $<0.001$ & 1 & 3.16 & 0.078 \\
\hline Month*distance & 13 & 0.84 & 0.622 & 11 & 0.54 & 0.875 & 13 & 1.29 & 0.225 & 11 & 1.28 & 0.242 \\
\hline Error & 140 & & & 124 & & & 140 & & & 124 & & \\
\hline
\end{tabular}

the same period in which the California Current is usually strongest and advective processes are active along the outer shelf, favouring upwelling of colder, relatively nutrient-rich waters that promoted an overall local increase of zooplankton activity and abundance. The moderate peaks of larval fish abundance and zooplankton biomass observed from January to May during the El Niño period suggest the damped recurrence of environmental conditions that enhance the primary and secondary production in coastal waters during normal periods.

\subsection{Seasonal pattern of phytoplankton abundance during the El Niño event}

Diatoms were several times more abundant than dinoflagellates at both depths ( 0 and $25 \mathrm{~m})$. There were no differences in abundance of diatoms or dinoflagellates between inshore and offshore, however there were significant seasonal differences $(p<0.05$; Table 2). The highest diatom abundance was found from March to May (Fig. 6). No clear patterns were observed in the case of dinoflagellates due to their lower abundance.

\subsection{Relation among environmental variables}

The PCA (Fig. 7) shows that both inshore and offshore, salinity and SST have high correlation with the first principal component (PC) and with high predictability could be reduced to one variable. We selected the inshore SST for GLM analyses because temperature is one of the most commonly measured oceanographic variables and is easy to record. MEI and UI are associated mainly with the second PC, but they seem to be associated with different oceanographic processes. The cross-correlation analysis indicates that the highest correlation between SST and UI was obtained with a lag of -1 month, meaning

Table 2

Results of GLM ANOVAs comparing phytoplankton abundances among sampling months and distance to shore during 1998

\begin{tabular}{|c|c|c|c|c|c|c|c|c|c|c|c|c|}
\hline & \multicolumn{6}{|c|}{ Sea surface } & \multicolumn{6}{|c|}{$25 \mathrm{~m}$ depth } \\
\hline & \multicolumn{3}{|c|}{ Diatom } & \multicolumn{3}{|c|}{$\underline{\text { Dinoflagellate }}$} & \multicolumn{3}{|c|}{ Diatom } & \multicolumn{3}{|c|}{ Dinoflagellate } \\
\hline & $d f$ & $F$ & $p$ & $d f$ & $F$ & $p$ & $d f$ & $F$ & $p$ & $d f$ & $F$ & $p$ \\
\hline Intercept & 1 & 30.27 & $<0.001$ & 1 & 42.08 & $<0.001$ & 1 & 111.65 & $<0.001$ & 1 & 39.34 & $<0.001$ \\
\hline Distance & 1 & 1.03 & 0.312 & 1 & 0.13 & 0.717 & 1 & 4.42 & 0.039 & 1 & 0.04 & 0.837 \\
\hline Month & 8 & 6.19 & $<0.001$ & 8 & 4.40 & $<0.001$ & 7 & 14.47 & $<0.001$ & 7 & 4.75 & $<0.001$ \\
\hline Distance*month & 8 & 0.26 & 0.978 & 8 & 0.49 & 0.860 & 7 & 2.05 & 0.060 & 7 & 0.92 & 0.498 \\
\hline Error & 84 & & & 84 & & & 74 & & & 74 & & \\
\hline
\end{tabular}




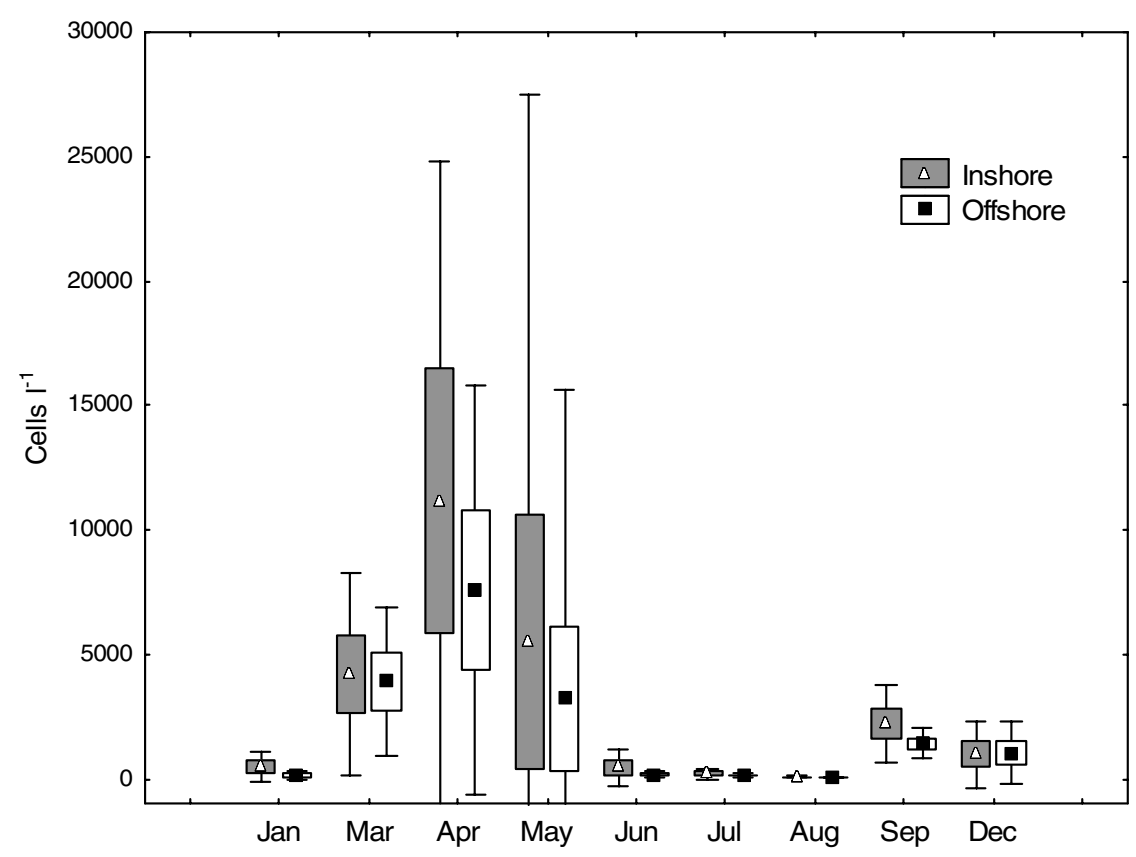

Fig. 6. Monthly mean values of phytoplankton represented by the sum of dinoflagellates and diatoms in the inshore and offshore sites. Boxes represent one standard error and vertical lines the $95 \%$ confidence interval.

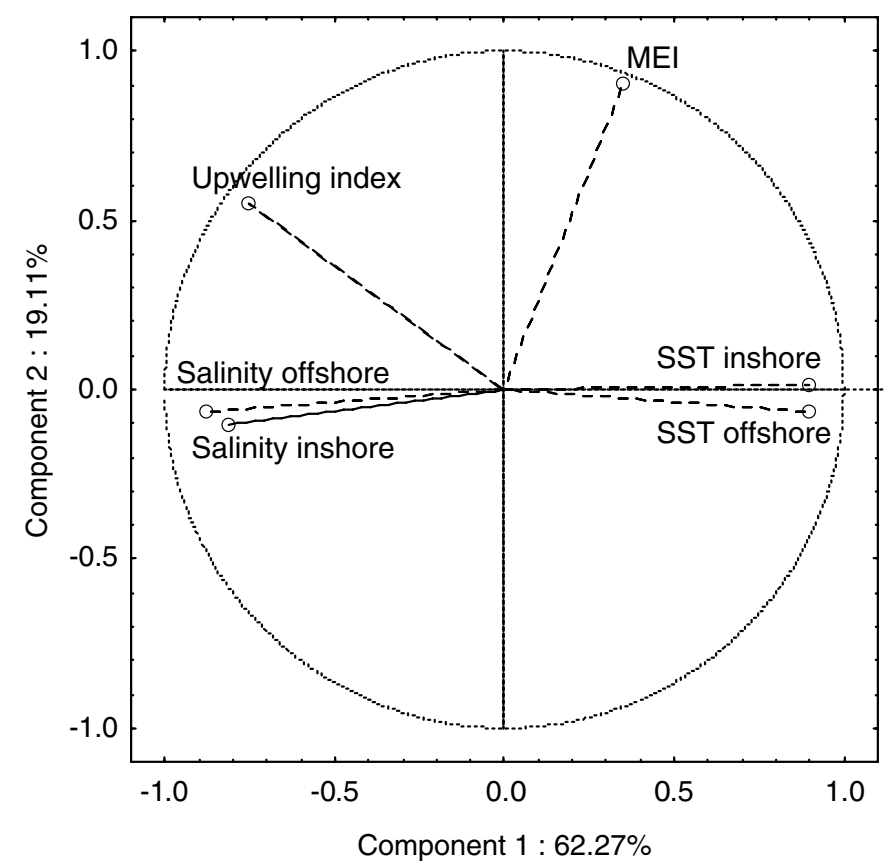

Fig. 7. Principal component analysis of the environmental variables taken simultaneously with the plankton samplings (salinity and SST) and other oceanographic variables representing the El Niño signal (MEI) and the regional upwelling index (UI). 

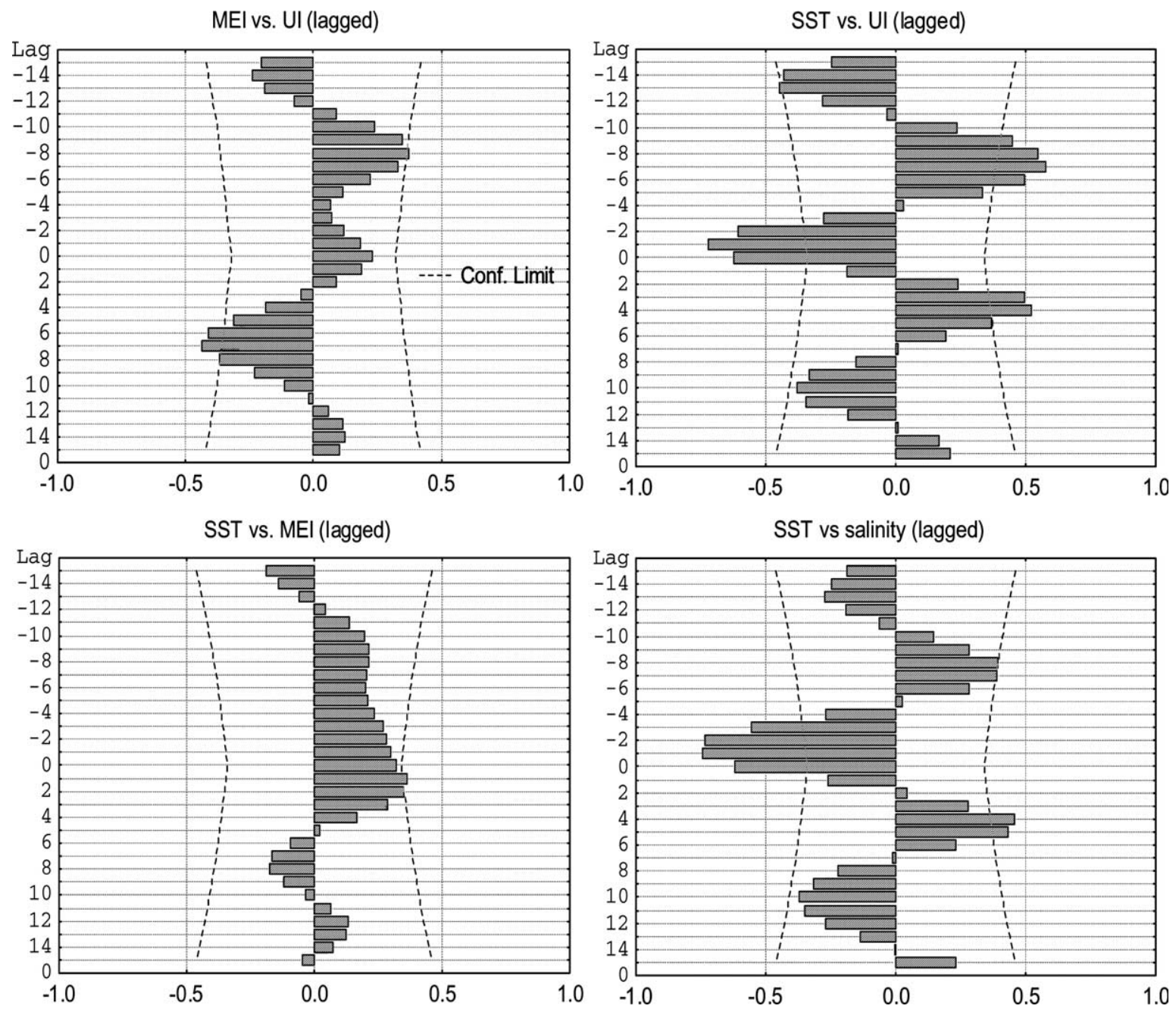

Fig. 8. Cross-correlations between the environmental variables employed to model the variability of the plankton community.

that climatic changes that control upwelling processes (estimated for one degree of latitude north from the study area) occurred one month before temperature shifts observed by us (Fig. 8). A clear 6-month harmonic component was observed in the variables. The highest correlation between SST and MEI was with a positive lag of MEI, which indicates that the ENSO signal takes 1 month to arrive at the study area, and no harmonic components were observed. SST and salinity showed their highest cross-correlation with a lag of -1 month.

\subsection{Generalized linear models of zooplankton and larval fish abundance}

MEI, UI and SST were the most influential variables affecting plankton and larval fish abundance, according to their frequency of appearance in the most parsimonious GLM models (Table 3). Time trend, distance from the coast, season, and the interaction of season and distance constituted a secondary group of variables. Total larval fish abundance, zooplankton biomass, and the abundance of Bregmac- 
Table 3

Generalized linear models (GLM) of abundance of zooplankton biomass and larval fish abundance (total and for each taxa)

\begin{tabular}{|c|c|c|c|c|c|c|c|c|}
\hline & \multicolumn{8}{|c|}{ Distance from } \\
\hline & MEI & UI & SST & The coast & Season & Trend & Interaction $^{\mathrm{a}}$ & $d f$ \\
\hline Larval fish abundance & $\times$ & $\times$ & & $x$ & $x$ & & & 5 \\
\hline Zooplanktic biomass & $\times$ & $\times$ & $x$ & $\times$ & $\times$ & & $\times$ & 8 \\
\hline Bregmaceros bathymaster & $x$ & $\times$ & & $x$ & $x$ & & & 5 \\
\hline Vinciguerria lucetia & $\times$ & $x$ & $x$ & $x$ & $x$ & $x$ & $\times$ & 9 \\
\hline Benthosema panamense & $x$ & $x$ & $x$ & $x$ & $x$ & $x$ & & 7 \\
\hline Gobionellus sp. & $\times$ & $\times$ & $\times$ & & $\times$ & $\times$ & $\times$ & 7 \\
\hline Lujanus spp. & $x$ & $x$ & $x$ & $x$ & $x$ & $\times$ & & 7 \\
\hline Syacium ovale & $\times$ & $\times$ & $\times$ & $\times$ & & $\times$ & $\times$ & 7 \\
\hline Euthynus lineatus & $\times$ & $x$ & $\times$ & $x$ & $x$ & $\times$ & & 6 \\
\hline Harengula thrissina & $x$ & $x$ & $x$ & $x$ & $x$ & $\times$ & & 6 \\
\hline Auxis sp. & $\times$ & $\times$ & $\times$ & & & $\times$ & $\times$ & 5 \\
\hline Pomacentridae & $\times$ & $\times$ & $x$ & $x$ & $\times$ & & & 5 \\
\hline Engraulidae & $x$ & $x$ & $x$ & $x$ & & & & 3 \\
\hline Sciaenidae & $\times$ & $x$ & $x$ & & & & & 1 \\
\hline Gobidae & $x$ & $\times$ & & & $x$ & $\times$ & $\times$ & 7 \\
\hline Dormitator latifrons & & & $x$ & & & & $x$ & 3 \\
\hline
\end{tabular}

Variables included in the most parsimonious models selected using best subset procedure based in the Akaike information criterion $(p<0.01$ in all cases) are shown.

${ }^{\text {a }}$ Distance $*$ season interaction

eros bathymaster, Engraulidae and Sciaenidae responded negatively to MEI (Table 4). The remaining species were related positively to MEI. The UI was positively related with the taxa that were negatively related with MEI. The SST was negatively related with most of the taxa and was positively related only with Auxis sp., Vinciguerria lucetia, Caranx spp., Euthynus lineatus, Lutjanus spp., and Pomacentridae. Clear negative trends were shown by $V$. lucetia, Benthosema panamense, Gobionellus sp., E. lineatus, Harengula thrissina and Auxis sp. Inshore stations were positively related with zooplankton biomass, larval fish abundance, B. bathymaster, H. thrissina and Lutjanus spp. (see Fig. 9). The taxa associated with offshore stations were B. panamense, Syacium ovale, V. lucetia, Engraulidae, E. lineatus and Pomacentridae. The variables responding positively to the California Current period were zooplankton biomass, larval fish abundance, and the abundance of $V$. lucetia, B. panamense, E. lineatus, Pomacentridae, Gobidae and B. bathymaster.

\section{Discussion}

\subsection{Oceanographic setting}

A distinct change in the hydrological pattern of the area, most probably caused by El Niño, became clear in July 1997. A weakening of the trade winds had resulted in a displacement of the Subsurface Equatorial Water toward the Mexican coast (Filonov, Tereshchenko, \& Monzon, 2003). This water mass has relatively high temperature and low salinity, with TS characteristics identical to those of the Pacific tropical surface water (PTSW). Eventually, this water mass drove the local water out of the upper layer.

\subsection{Temporal variability of the zooplankton biomass and larval fish abundance}

A clear interannual decline was observed in the zooplankton biomass and ovarall larval fish abundance (see Fig. 5), but a seasonal response was also observed. The length of the time series limits the linear trend, 
Table 4

Parameters of generalized linear models fitted to (a) zooplankton biomass, larval fish abundance and most abundant larval fish species, and (b) target species of the local small-scale fisheries

\begin{tabular}{|c|c|c|c|c|c|c|c|c|c|c|c|c|}
\hline & Level of effect & $\begin{array}{l}\text { Zooplanktic } \\
\text { biomass }\end{array}$ & $\begin{array}{l}\text { Larval fish } \\
\text { abundance }\end{array}$ & $\begin{array}{l}\text { Auxis } \\
\text { sp. }\end{array}$ & $\begin{array}{l}\text { Benthosema } \\
\text { panamense }\end{array}$ & $\begin{array}{l}\text { Bregmaceros } \\
\text { bathymaster }\end{array}$ & $\begin{array}{l}\text { Dormitator } \\
\text { latifrons }\end{array}$ & Gobidae & $\begin{array}{l}\text { Gobionellus } \\
\mathrm{sp}\end{array}$ & $\begin{array}{l}\text { Harengula } \\
\text { thrissina }\end{array}$ & $\begin{array}{l}\text { Syacium } \\
\text { ovale }\end{array}$ & $\begin{array}{l}\text { Vinciguerria } \\
\text { lucetia }\end{array}$ \\
\hline \multicolumn{13}{|l|}{$a$} \\
\hline Intercept & & 7.73 & 6.39 & -88.81 & 66.66 & 6.19 & 5.67 & 4.29 & 3513.30 & 158.15 & 6.43 & -21.30 \\
\hline MEI & & -0.46 & -0.80 & 4.33 & 24.36 & -0.95 & 0.10 & 0.41 & 88.20 & 23.44 & 0.49 & 1.25 \\
\hline UI & & 0.00 & 0.01 & -0.11 & -0.02 & 0.01 & 0.00 & -0.01 & -5.23 & 0.10 & -0.01 & -0.01 \\
\hline SST & & -0.06 & 0.00 & 3.40 & -2.19 & -0.01 & -0.10 & -0.30 & -127.89 & -6.41 & -0.47 & 0.86 \\
\hline Trend & & 0.00 & 0.00 & -0.94 & -3.50 & 0.02 & 0.00 & 0.32 & -12.36 & -3.59 & 0.36 & -0.16 \\
\hline Distance & Inshore & 0.28 & 0.14 & 0.28 & -0.85 & 0.11 & -0.03 & -0.17 & -56.51 & 1.51 & -1.01 & -0.62 \\
\hline Season & Transition & 0.06 & -0.02 & 0.71 & 8.29 & 0.03 & -0.04 & -0.06 & 46.20 & 23.51 & 0.03 & 0.34 \\
\hline Season & California Current & 0.49 & 0.39 & 13.60 & 2.94 & 0.47 & 0.23 & 0.73 & 7.40 & -53.71 & 0.62 & 3.45 \\
\hline Distance $*$ season & Inshore*transition & 0.18 & -0.03 & 0.49 & -0.14 & -0.06 & 0.09 & -0.48 & 57.63 & 2.37 & -0.54 & -0.26 \\
\hline \multirow[t]{2}{*}{ Distance $*$ season } & $\begin{array}{l}\text { Inshore*California } \\
\text { Current }\end{array}$ & -0.23 & 0.12 & -0.85 & 0.07 & 0.15 & -0.24 & 0.36 & -41.43 & 1.48 & 0.64 & 0.32 \\
\hline & \multicolumn{2}{|l|}{ Level of effect } & \multicolumn{2}{|l|}{ Caranx spp. } & Engraulidae & \multicolumn{2}{|c|}{ Euthynus lineatus } & \multicolumn{2}{|c|}{ Lujanus spp. } & \multicolumn{2}{|c|}{ Pomacentridae } & Sciaenidae \\
\hline \multicolumn{13}{|l|}{$b$} \\
\hline Intercept & & & 4.95 & & -0.32 & -68.62 & & -64.62 & & -88.40 & & 51.76 \\
\hline MEI & & & 24.61 & & -35.19 & 13.32 & & 2.66 & & 0.77 & & -67.34 \\
\hline UI & & & -0.03 & & 0.07 & -0.05 & & 0.02 & & -0.02 & & 0.13 \\
\hline SST & & & 0.19 & & -0.27 & 2.01 & & 1.23 & & 2.78 & & -3.35 \\
\hline Trend & & & -3.92 & & -2.41 & -0.98 & & 1.09 & & 0.42 & & -0.50 \\
\hline Shore distance & \multicolumn{2}{|l|}{ Inshore } & -0.43 & & -0.08 & -0.23 & & 1.12 & & -1.56 & & -0.47 \\
\hline Season & \multicolumn{2}{|l|}{ Transition } & 8.17 & & -11.40 & 3.91 & & -0.99 & & -4.35 & & 4.11 \\
\hline Season & \multicolumn{2}{|c|}{ California Current } & 7.88 & & -6.37 & 8.01 & & -4.11 & & 8.58 & & -25.81 \\
\hline Distance $*$ season & \multicolumn{2}{|c|}{ Inshore*transition } & 0.50 & & -2.88 & 0.12 & & -0.81 & & -2.29 & & -0.20 \\
\hline Distance $*$ season & \multicolumn{2}{|c|}{ Inshore*California Current } & -0.61 & & 1.93 & -0.22 & & 1.78 & & 0.66 & & 1.95 \\
\hline
\end{tabular}

Significant effects $(p<0.05)$ are shown in bold. 

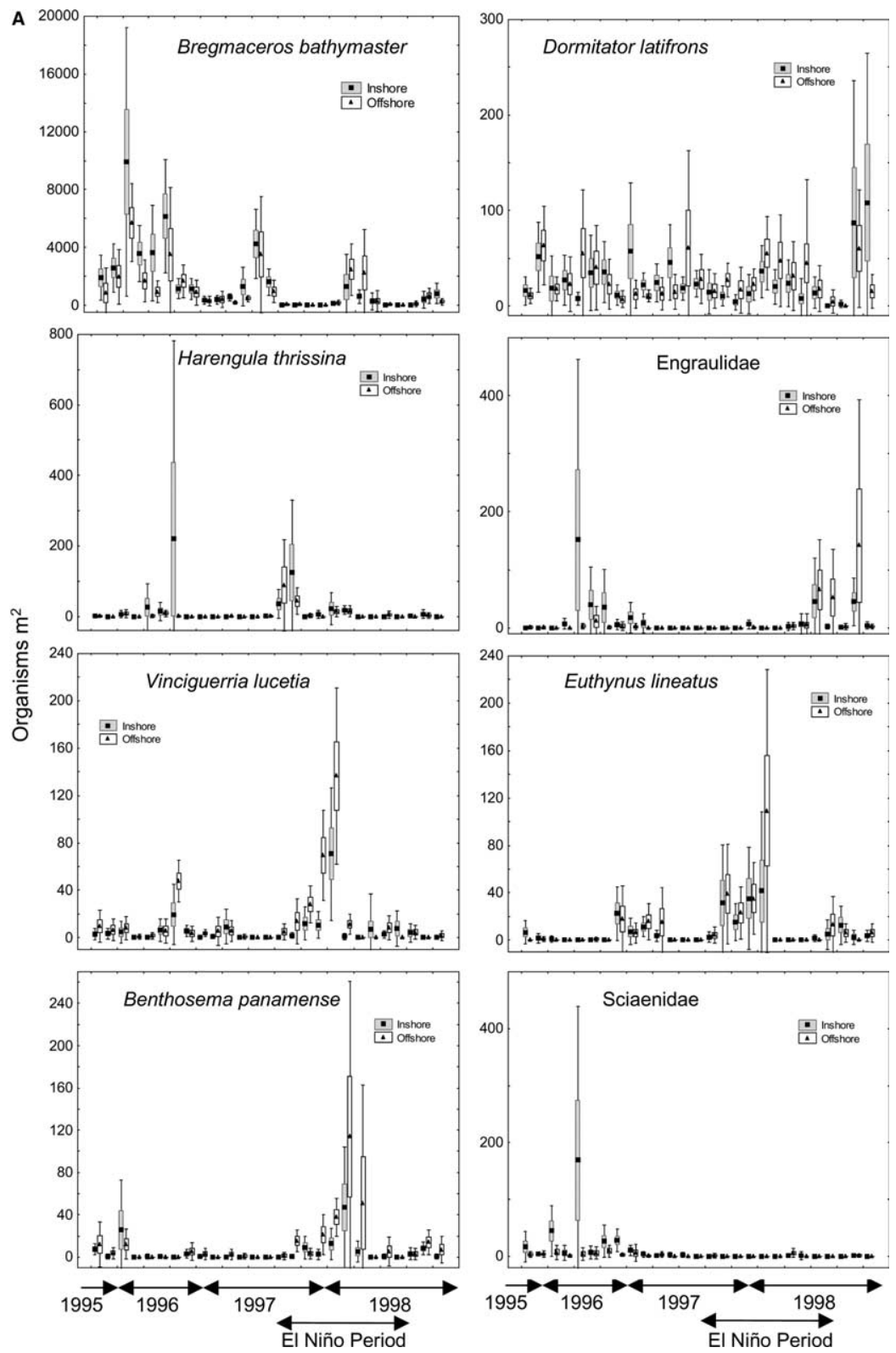

Fig. 9. Time series of abundance of the most important larval fish taxa prior to and during the El Niño $1997-1998$ event in both inshore and offshore sites. Boxes represent one standard error while vertical lines represent the $95 \%$ confidence interval.

and probably the resilient response of the plankton community to the ENSO events takes longer than the observations lasted. Along the North American Pacific coast, the Pacific decadal oscillation (PDO) and ENSO events determine the multi-year environmental changes, which include strong variations of primary and secondary production and fish populations (Smith \& Moser, 2003). In the California Current system (CC), there are several long-term, decadal, plankton series: primary production (Hernández, Gaxiola- 

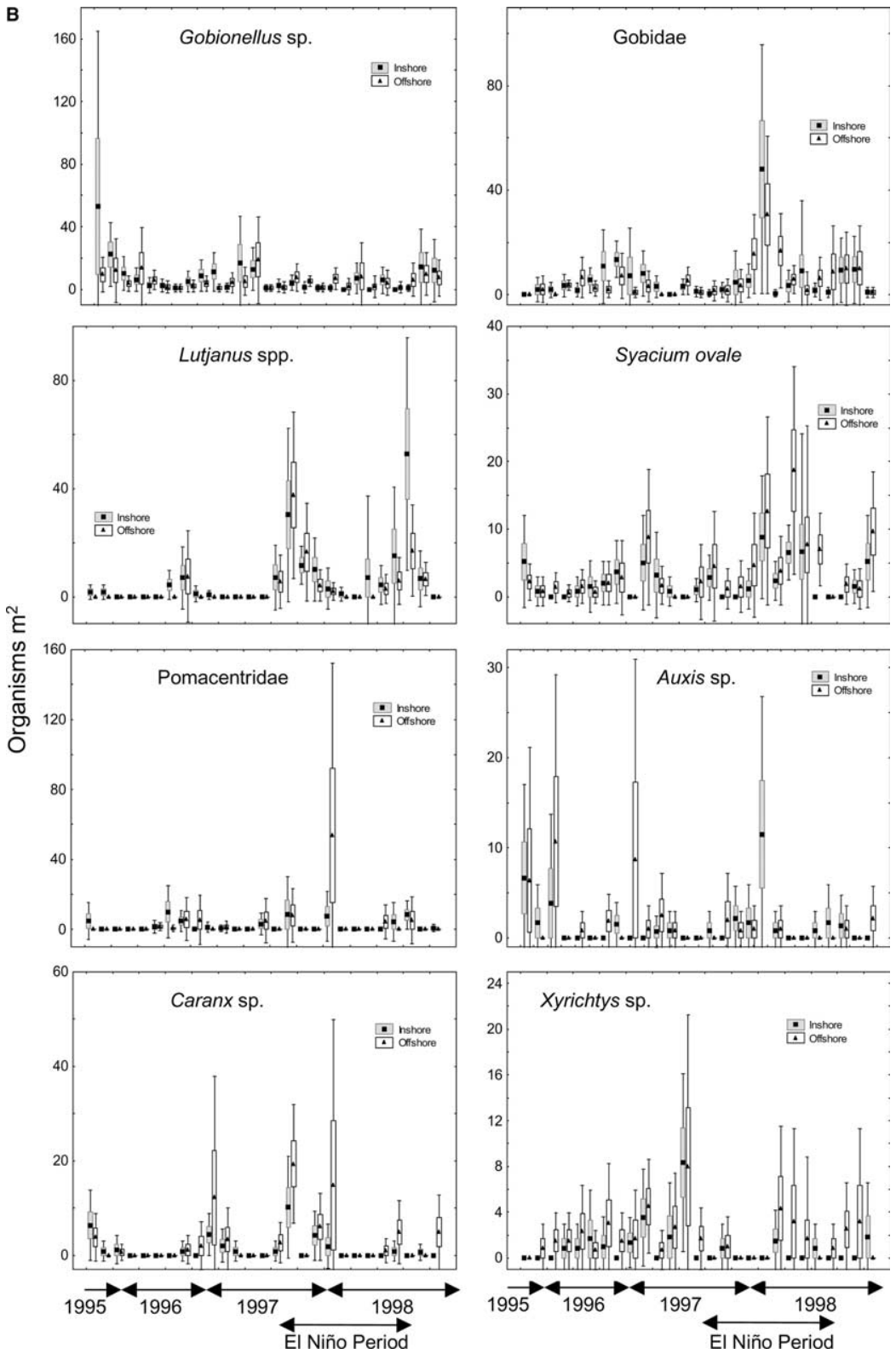

Fig. 9 (continued)

Castro, Alvarez-Borrego, Gómez-Valdés, \& Nájera-Martínez, 2003), tunicates (Lavaniegos \& Ohman, 2003), copepods (Peterson \& Keister, 2003), euphausiids (Brinton \& Townsend, 2003) and larval fishes (Smith \& Moser, 2003), and several temporal components have been identified. Besides, indicators of the pelagic ecosystem, such as zooplankton biomass or abundance of different groups, are sensitive to different temporal scales. The main characteristic of the community response could be determined by the 
species-specific responses to the environmental conditions, recorded as shifts in the species composition at the decadal scale and a cyclic recomposition at the seasonal scale.

There are three main sources of temporal variability in northeastern Pacific waters: the decadal scale associated with regime shifts, the interannual scale associated with ENSO events and the hydroclimatic seasonality. However, the degree of influence, at least at the interannual scale, depends upon the geographic location. ENSO-scale variability (2-7 year) is dominant in the eastern equatorial Pacific and decadal scale variability (10-30 year) is dominant in the northeastern Pacific (Fiedler, 2002). The studied area is located south of the mouth of the Gulf of California, and its seasonal hydroclimatic cycle shows an influence of tropical and subtropical water masses (Filonov \& Tereshchenko, 2000; Filonov et al., 2000) The zooplankton community responds to this variability pattern (Franco-Gordo et al., 2001a, 2001b, 2002, 2003). However there is no information available to determine whether decadal or interannual variabilities are the most influential sources, due the lack of long-term time series of oceanographic and biological variables in the central Mexican Pacific.

The impoverishment of pelagic habitats is one of the most cited effects of ENSO events (Chavez et al., 1999). They produce a decline of primary, secondary and fish production, resulting in an ecosystem reorganization (Fiedler, 2002). However, the sign and the magnitude of the change could vary with no geographical pattern. The zooplankton biomass decreased markedly in our area of study during El Niño 1997-1998, and similar results were recorded along the CC system (Lavaniegos et al., 2002; Mackas \& Galbraith, 2002). However no changes were observed off northern Chile (González, Sobarzo, Figueroa, \& Nöthing, 2000) or off Baja California (Lavaniegos et al., 1998). The variability of the zooplankton biomass during ENSO events could be affected by the species composition: in Chile no changes of zooplankton biomass were observed, but the relative abundance of small-sized copepods increased (González et al., 2000), whereas in a region of the CC higher biomasses were due to high abundance of warm-affinity salps (Lavaniegos \& Ohman, 2003) and copepods (Lavaniegos et al., 2003). Changes in zooplankton biomass are often secondary to changes in species composition (Fiedler, 2002). In several zooplankton groups, southern species shifted their distribution northward along the CC system during the El Niño events of 1958-1959, 1978-1979, 1982-1983, 1986-1987 and 1997-1998, and cold-water California Current species were less common (Table 5). In fact one of the main effects in the planktonic community during El Niño events in subtropical and temperate areas is the tropicalization of the species composition (Table 5).

\subsection{The prevalence of an attenuated typical seasonality during the El Niño event in inshore waters}

Seasonal fluctuations in zooplankton biomass and larval fish abundance are widely reported in the Pacific Ocean (Chiba \& Saino, 2003; Franco-Gordo et al., 2001a, 2001b; Rodríguez-Graña \& Castro, 2003), inclusive of ENSO events (Mackas \& Galbraith, 2002), as our results also show. The monthly variation of the abundance of diatoms and dinoflagellates, of zooplankton biomass and larval fish abundance during 1997-1998 showed a prevalence of typical, although attenuated, hydroclimatic patterns during E1 Niño. The prevalence of typical seasonal pattern in the assemblages of coastal adult fish (Godínez-Domínguez et al., 2000; Madrid \& Sánchez, 1997) and soft-bottom macroinvertebrates (Godínez-Domínguez et al., in review) has been reported for the central Mexican Pacific. The decreases in primary production are directly linked to changes in nutrient supply, evidence for physical forcing of the biological response. The effects off Central (Chavez et al., 2002) and Southern California (Bograd \& Lynn, 2001) were similar to those in the equatorial Pacific (Chavez et al., 1999). During the El Niño period diatoms were more abundant than dinoflagellates, and the same occurred off central California, where dinoflagellates and picophytoplankton showed low abundances during El Niño (Chavez et al., 2002). According to those authors, the high diatom abundance supports the observation that coastal processes (e.g., upwelling) that favor diatoms must have remained active during El Niño in inshore waters. However, the carbon/ 
Zooplankton studies carried out during El Niño events along the Northeast Pacific

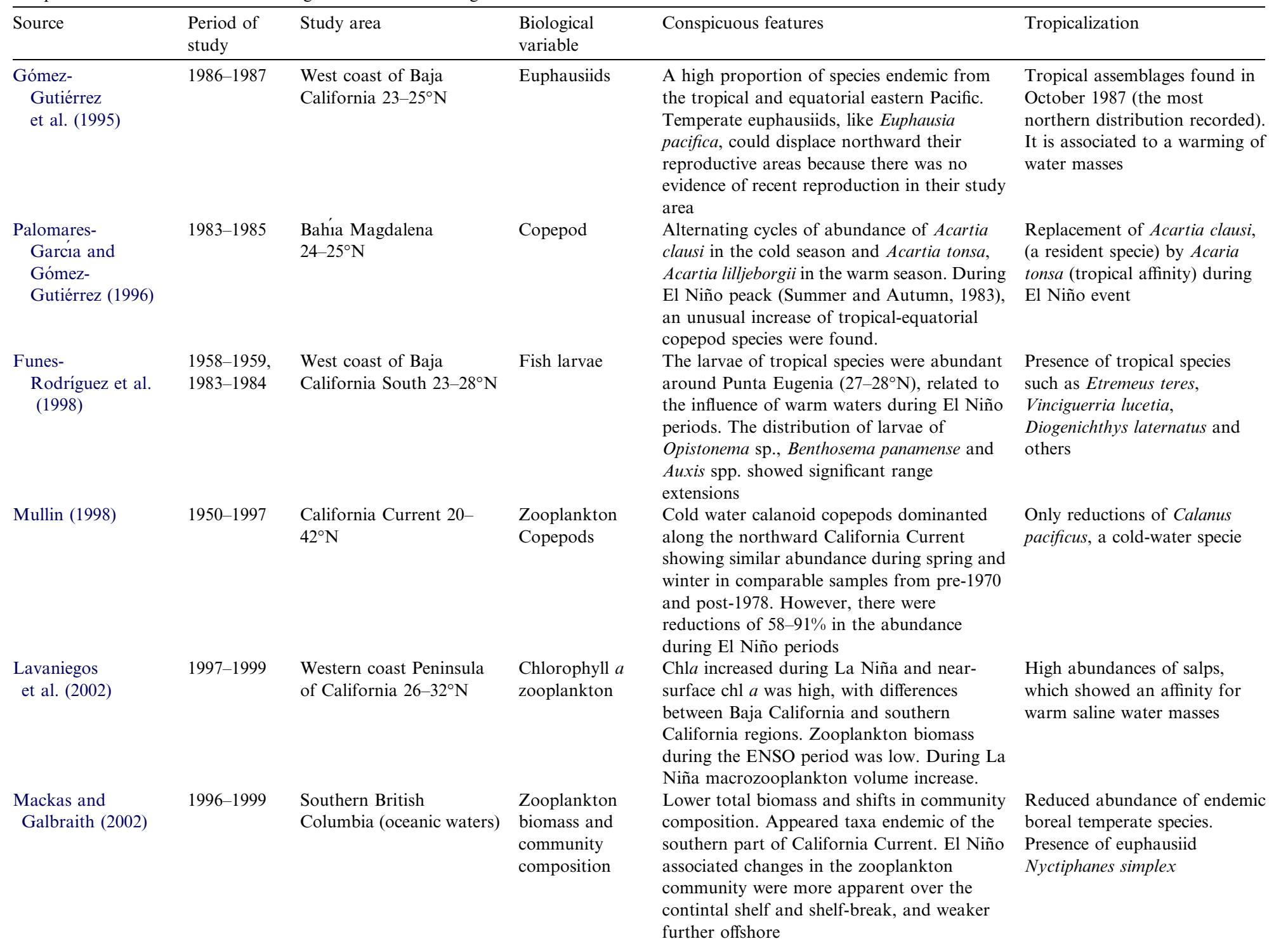



$\begin{array}{lll}\begin{array}{l}\text { Marinovic et al. } \\ \text { (2002) }\end{array} & \begin{array}{l}\text { Monterrey Bay } 36^{\circ} 55^{\prime}- \\ 36^{\circ} .39^{\circ} \mathrm{N}\end{array}\end{array}$ $\begin{array}{cll}\text { Sánchez-Velasco } & 1997-1998 & \begin{array}{l}\text { Gulf of California 26- } \\ \text { et al. (2002) }\end{array} \\ 30^{\circ} \mathrm{N}\end{array}$

\section{Avalos-García}

et al. (2003)

Brinton and Townsend

(2003)

Funes-

Rodríguez

et al. (2003)

Lavaniegos et al., 2003
Zooplankton

Euphausiids

1997-1998

Gulf of California 26$30^{\circ} \mathrm{N}$

1950-2002

Southern California

Current $32-35^{\circ} \mathrm{N}$

1982-2000 West coast of Baja

California $22-30^{\circ} \mathrm{N}$

1997-1998

Western coast Peninsula of California $26-32^{\circ} \mathrm{N}$

larvae

Chlorophyll $a$ Zooplankton
Abundance decreased dramatically in summer 1997. Cold water species Eufhausia pacifica and Thysanoessa spinifera

decreased. Zooplankton and euphausiid abundance and composition returned gradually to a typical state in 1998

High values of zooplancton biomass and Engraulis mordax during and after the El

Niño. Both groups concentrated close to isla Angel de la Guarda and Isla Tiburon, along coldest zone

Low larval abundance of cold water species like Sardinops sagax and Scomber japonicus. The El Niño 1997-1998 condition were more favorable for tropical and subtropical species

Euphausia pacifica and Nematoscelis difficilis, the most abundant cold water species during 1950-2002, decreased during El Niño events. Subtropical species like: E. eximia, E. gibboides, and $E$. recurva, were present in small numbers, most notably during El Niño events

Mesopelagic fish The structure and density is controlled

to a large extend by the seasonal

environmental dynamics, however the larval assemblages showed changes associated with El Niño warning event, the southern area and with seasonality in the northern area

Regional differences in zooplankton Salps Copepods chlorophyll remained constant. Changes in species composition of zooplankton affect the biomass values, and these changes were due to the increase of tropical species
Presence of Nyctiphanes simplex, a southern latitude species

\section{No data}

High abundance of Benthosema panamense could be due to ocean warning

Tropical species as: $E$

distinguenda, E. tenera, $E$.

lamelligera and $E$. diomedae, were recorded during 1998, the only time in the 52 years of survey.

High abundances of warm-water species such Vinciguerria lucetia, Opistonema spp. and Benthosema panamense

Largest values of salps and small tropical copepods as

Nannocalanus minor and

Eucalanus subtenuis, during the peak of the El Niño

(continued on next page) 
Table 5 (continued)

\begin{tabular}{|c|c|c|c|c|c|}
\hline Source & $\begin{array}{l}\text { Period of } \\
\text { study }\end{array}$ & Study area & $\begin{array}{l}\text { Biological } \\
\text { variable }\end{array}$ & Conspicuous features & Tropicalization \\
\hline $\begin{array}{c}\text { Lavaniegos and } \\
\text { Ohman (2003) }\end{array}$ & 1951-2002 & $\begin{array}{l}\text { Southern California } \\
\text { Current } 26-32^{\circ} \mathrm{N}\end{array}$ & Tunicates & $\begin{array}{l}\text { Evidence for ecosystem change between El } \\
\text { Niño 1976-1977 and 1998-1999. However no } \\
\text { clear long-term patterns respect to El Niño, as } \\
\text { both total salps biomass and that of } \\
\text { individual species decreased in some El Niño } \\
\text { years and increased in others }\end{array}$ & $\begin{array}{l}\text { The rare subtropical Doliolum } \\
\text { denticulatum was present } \\
\text { predominantly during the warm } \\
\text { phase }\end{array}$ \\
\hline $\begin{array}{l}\text { Smith and } \\
\text { Moser (2003) }\end{array}$ & $1951-2003$ & $\begin{array}{l}\text { California Current } 20- \\
42^{\circ} \mathrm{N}\end{array}$ & Fish larvae & $\begin{array}{l}\text { Mesopelagic larvae of the southhern offshore } \\
\text { species had the greasted response to the } \\
\text { regime shift of 1976-77. Cool water } \\
\text { conditions generally are asociated with } \\
\text { increased zooplankton production which } \\
\text { would suggest higher larval fish production } \\
\text { and survival }\end{array}$ & $\begin{array}{l}\text { Vinciguerria lucetia showed a } \\
\text { near two-fold increase. It was the } \\
\text { most abundant larval species in } \\
\text { the southern California Bight }\end{array}$ \\
\hline
\end{tabular}


chlorophyll ratio increased greatly, and primary production per unit of carbon decreased dramatically, indicative of nutrient-limited phytoplankton.

\subsection{Cross-shelf distribution of the phytoplankton abundance, zooplankton biomass and larval fish abundance}

A clear inshore-offshore structure of the larval fish and zooplankton community was observed during the pre-ENSO period, with inshore stations showing the largest abundances. During the ENSO period no spatial structure was found. Only for diatoms at $25 \mathrm{~m}$ depth were the inshore-offshore differences significant. During the pre-ENSO period, an inshore-offshore seasonal pattern has been observed elsewhere for the zooplankton biomass, and in the study area for the larval fish abundance and assemblages (Franco-Gordo et al., 2001a, 2001b, 2003). This small-scale spatial pattern seems to be related mainly to coastal advective processes (Franco-Gordo et al., 2003), and during the normal (La Niña) season of tropical oceanographic conditions (with vertical thermal stratification), a well-differentiated inshore-offshore gradient was observed. The coastal advective processes during the cold season produce a spatial homogenization of the zooplankton biomass and the larval fish assemblage. Typical ENSO effects are defined by strong vertical and horizontal stratification, which modifies the advective regime. However, upwelling continues in the coastal waters, but the upwelled water has low nutrient concentrations and the productivity declines sharply (Chavez et al., 2002). These factors could explain the prevalence of a normal but attenuated seasonality.

\subsection{Response of the larval fish species and zooplankton biomass to environmental variability}

Processes with Interannual scales appear to control environmental variability in the studied area, and together with seasonality determine the fluctuations of larval fish abundance and zooplankton biomass. A small-scale spatial pattern defined by the cross-shore distribution is controlled by hydroclimatic seasonality, but it is also modulated by interannual anomalies.

The most parsimonious GLM models for larval fish abundance included the environmental variables MEI and UI and the seasonal and spatial (cross-shore) variability. These results reinforce the conclusion that the seasonal component determines the fish production patterns, and is affected by interannual processes like the El Niño event. Spawning timing and location, larval life duration, larval behaviour and coastal processes affect the composition and spatial distribution of the larval fish community (Mullin, 1993). However, during El Niño events, the composition and spatial structure of the larval fish community are affected mainly by the physical environmental stress and the changes in transport patterns along the North American coast (Sanchez-Velasco, Shirasago, Cisneros-Mata, \& Avalos-Garcia, 2000; Smith \& Moser, 2003), and that of Chile (Rodríguez-Graña \& Castro, 2003). It has been hypothesized that spawning strategies in marine fish populations have evolved in synchrony with prevailing oceanographic conditions to give rise to persistent multi-species assemblages of fish larvae (Doyle, Morse, \& Kendall, 1993; Frank \& Leggett, 1983; Parrish, Nelson, \& Bakun, 1981), and for this reason the larval fish species change in a similar way in relation to spatial and seasonal patterns of primary and secondary production, but are strongly affected by interannual global processes.

A trend of increase with time was included in the models of Lutjanus spp., S. ovale and Gobidae. The Lutjanus species are the most valuable target species of the small-scale fisheries in the region, and their catches fluctuate strongly, with major peaks during the 1999 La Niña event (Rojo-Vázquez personal communication). The linear trend of the lutjanid larvae could not be easily related to the abundance of the reproductive stock, mainly due to catchability changes of the coastal fishes (demersal and pelagic) during ENSO events (Godínez-Domínguez et al., 2000; Rojo-Vázquez personal communication). Similar trend of increase in the some larval fish species in the CC system have been reported by Smith and Moser (2003). $V$. lucetia is one of the dominant mesopelagic species in the entire eastern tropical Pacific, and it became one of 
the most abundant larval taxa in the Southern California Bight during the two last decades (Smith \& Moser, 2003). According to these authors, the recomposition of the larval fish assemblages over the interannual and longer periods, where a regime shift has occurred, cannot be explained only by the biogeographic affinity of the species, and the fisheries impact and management strategies should be considered important forces to structure larval fish communities.

Bregmaceros bathymaster is the most abundant species of fish larvae in the tropical Mexican Pacific (Franco-Gordo et al., 2001b), and it is scarce in the California Current system (Moser et al., 1993). The small size of Bregmaceros as adults (ca. $12 \mathrm{~cm}$ ) makes them unattractive for fisheries; however, they have been described as ecologically significant in oceanic food webs (Zavala-García \& Flores-Coto, 1994). The species is considered to have a tropical affinity, and the adults occur mainly in oceanic waters (Norcross \& Shaw, 1984); however, the larvae are more abundant in inshore waters, and they responded positively to UI and negatively to MEI. Apparently the general rule in both tropical and temperate regions could be that the conditions associated with cool waters generally are associated with increased zooplankton production that would promote higher larval fish production and survival (Smith \& Moser, 2003).

\section{Acknowledgements}

This research was partially founded by the University of Guadalajara, CONACyT México and by the Ministerio de Ciencia y Tecnología, Spain (Grant REN2000-0446). The collaboration of the crew of the BIP-V made this work possible, Celestino Preciado Gudiño (captain) and Salomón Medina Morales and Daniel Kosonoy Aceves.

\section{References}

Ainley, D. G., Syderman, W. J., \& Norton, J. (1995). Upper trophic level predators indicate interannual negative and positive anomalies in the California Current food webs. Marine Ecology Progress Series, 118, 69-79.

Avalos-García, C., Sánchez-Velasco, L., \& Shirasago, B. (2003). Larval fish assemblages in the Gulf of California and their relation to hydrographic variability (autum 1997-1998). Bulletin of Marine Science, 72(1), 63-76.

Badan, A. (1997). La corriente costera de Costa Rica en el Pacífico Mexicano. In Lavin, M.E. (Ed.), Contribuciones a la Oceanografia física en México. Monografía No. 3 (pp. 99-112), Unión Geofísica Mexicana.

Barber, R. T., \& Chavez, F. P. (1983). Biological consequences of El Niño. Science, 222, 1203-1210.

Beers, J. R. (1976). Volumetric methods. In H. F. Steedman (Ed.), Zooplankton, fixation and preservation. Monographs on ocean. Method. No. 4 (pp. 56-60). Paris: UNESCO Press.

Bograd, S. T., \& Lynn, R. J. (2001). Physical-biological coupling in the California Current during the 1997-99 El Niño-La Niña cycle. Geophysical Research Letters, 28, 275-278.

Brinton, E., \& Townsend, A. (2003). Decadal variability in abundances of the dominant euphausiid species in southern sector of the California Current. Deep-Sea Research II, 50, 2449-2472.

Brodeur, S. T., Francis, R. C., \& Pearcy, W. G. (1992). Food consumption of juvenile coho (Oncorhynchus kisuteh) and chinook salmon (Oncorhynchus tshawytscha) on the continental shelf off Washington and Oregon. Canadian Journal of Fisheries and Aquatic Sciences, 49, 1670-1685.

Chavez, F. P., Struton, P. J., Friederich, G. E., Feely, R. A., Feldman, G. C., Foley, D. G., et al. (1999). Biologial and Chemical Response of the Equatorial Pacific Ocean to the 1997-98 El Niño. Science, 286, 2126-2131.

Chavez, F. P., Pennigton, J. T., Castro, C. G., Ryan, J. P., Michisaki, R. P., Schilining, B., et al. (2002). Biological and chemical consequences of the 1997-1998 El Niño in central California waters. Progress in Oceanography, 54, $205-232$.

Chelton, D. B., Bernal, P. A., \& McGowan, J. A. (1982). Large-scale interannual physical and biological interactions in the California Current. Journal of Marine Research, 40, 1095-1125.

Chiba, S., \& Saino, T. (2003). Variation in mesozooplankton community structure in the Japan/East Sea (1991-1999) with possible influence of the ENSO scale variability. Progress in Oceanography, 57, 317-339.

Connolly, S. R., \& Roughgarden, J. (1999). Increased recruitment of northeast Pacific barnacles during the 1997 El Niño. Limnology and Oceanography, 44, 466-469. 
Doyle, M. J., Morse, W. W., \& Kendall, A. W. Jr., (1993). A comparison of larval fish assemblages in the temperate zone of the northeast Pacific and northwest Atlantic oceans. Bulletin of Marine Science, 53, 588-644.

Ebert, T. A., Schroeter, S. C., Dixon, J. D., \& Kalvass, P. (1994). Settlement patterns of red and purple sea urchins (Strongylocentrotus franciscanus and S. purpuratos) in California, USA. Marine Ecology Progress Series, 111, 41-52.

Enfield, D. B. (1981). Thermally driven wind variability in the planetary boundary layer above Lima, Peru. Journal of Geophysical Research, 86, 2005-2016.

Fedorov, A. V., \& Philander, G. (2000). Is El Niño Changing? Science, 288, 1997-2002.

Fiedler, P. C. (1984). Some effects of El Niño 1983 on the northern anchovy. California Cooperative Oceanography Fisheries Investigation Report, 25, 53-58.

Fiedler, P. C. (2002). Environmental change in the eastern tropical Pacific Ocean: review of ENSO and decadal variability. Marine Ecology Progress Series, 244, 265-283.

Filonov, A. E., Monzón, C. O., \& Tereshchenko, I. E. (1996). A technique for fast conductivity-temperature-depth oceanographic surveys. Geofisica Internacional, 35, 415-420.

Filonov, A. E., \& Tereshchenko, I. (2000). El Niño 1997-98, monitoring in mixed layer at the Pacific ocean near Mexico's west coast. Geophysical Research Letters, 27, 705-708.

Filonov, A. E., Tereshchenko, I. E., Monzón, C. O., González-Ruelas, M. E., \& Godínez-Domínguez, E. (2000). Variabilidad estacional de los campos de temperatura y salinidad en la zona costera de los estados de Jalisco y Colima, México. Ciencias Marinas, 26(2), 303-321.

Filonov, A. E., Tereshchenko, I., \& Monzon, C. O. (2003). Hydrographic monitoring of El Niño $97-98$ off the coast of southwest Mexico. Geofisica Internacional, 42(3), 1-6.

Franco-Gordo, C., Godínez-Domínguez, E., \& Suárez-Morales, E. (2001a). Zooplancton biomass variability in the Mexican Eastern Tropical Pacific. Pacific Science, 55, 191-202.

Franco-Gordo, C., Godínez-Domínguez, E., Suárez-Morales, E., \& Flores-Vargas, R. (2001b). A seasonal survey of the fish larvae community of the central Pacific coast of México. Bulletin of Marine Science, 68, 383-396.

Franco-Gordo, C., Godínez-Domínguez, E., \& Suárez-Morales, E. (2002). Larval fish assemblages in waters off the central Pacific coast of Mexico. Journal of Plankton Research, 24, 775-784.

Franco-Gordo, C., Godínez-Domínguez, E., Suárez-Morales, E., \& Vásquez-Yeomans, L. (2003). Diversity of ichthyoplankton in the central Mexican Pacific: a seasonal survey. Estuarine Coastal and Shelf Science, 57, 111-121.

Frank, K. T., \& Leggett, W. C. (1983). Multispecies larval fish associations: accident or adaptation?. Canadian Journal of Fisheries and Aquatic Science, 40, 754-762.

Fulton, J. D., \& LeBrasseur, R. J. (1985). Interannual shifting of the subarctic boundary and some of the biotic effects on juvenile salmonids. In W. S. Wooster \& D. L. Fluharty (Eds.), El Nino North, Nino effects in the eastern subarctic Pacific Ocean (pp. 237-247). Seattle: University of Washington Press.

Funes-Rodríguez, R., Fernández-Alamo, M. A., \& González-Armas, R. (1998). Larvas de peces recolectadas durante dos eventos El Niño en la costa occidental de Baja California Sur, México, 1958-1959 y 1983-1984. Oceánides, 13(1), $67-75$.

Funes-Rodríguez, R., Hinojosa, A., Jiménez, P., Hernández, M., \& Zárate, A. (2003). Mesopelagic fish larvae along the west coast of Baja California related to El Niño events. In II Plankton Simposium, 16-19 October, Vigo Spain.

Godínez-DomíFreire, E., \& Freire, J. (2003). An information-theoretic approach for selection of spatial and temporal models of community organization. Marine Ecology Progress Series, 253, 17-24.

Godínez-Domínguez, E., Freire, J., Franco-Gordo, C., \& González-Sansón, G. (in review). Hierarchical organization of spatial and temporal patterns of macrobenthic assemblages in the tropical Pacific continental shelf. Marine Biology.

Godínez-DomíRojo-Vázquez, E., Rojo-Vázquez, J., Piña-Galván, V., \& Aguilar-Palomino, B. (2000). Change in the structure of a coastal fish assemblage exploited by a small scale gillnet fishery during and El Niño-La Niña event. Estuarine Coastal and Shelf Science, 51, 773-787.

Gómez-Gutiérrez, J., Palomares-García, R., \& Gendron, D. (1995). Community structure of the euphausiid populations along the west coast of Baja California, México, during the weak ENSO 1986-1987. Marine Ecology Progress Series, 120, 41-51.

González, H. B., Sobarzo, M., Figueroa, D., \& Nöthing, E. M. (2000). Composition, biomass and potential grazing impact of the crustacean and pelagic tunicates in the northern Humbolt Current area off Chile: differences between El Niño and non-Niño years. Marine Ecology Progress Series, 195, 201-220.

Graybill, M. R., \& Hodder, J. (1985). Effects of the 1982/83 El Nino on the reproductive success of six species of marine birds in Oregon. In Proceedings of the 1982/83 El Niño effects in the subartic Pacific conference. Washington Sea Grant Publication.

Griffiths, F.B., Fleminger, A. \& Vannucci, M. (1976). Shipboard and curating techniques. In UNESCO, De. Zooplankton fixation and preservation. Monograph of the oceanographic methodology (pp. 17-31).

Hernández, B., Gaxiola-Castro, G., Alvarez-Borrego, S., Gómez-Valdés, J., \& Nájera-Martínez, S. (2003). Interannual variability of new production in the southern region of the California Current. Deep Sea Research II, 50, 2423-2430.

Hasle, G. R. (1978). Using the inverted microscope. In A. Sournia (Ed.), Phytoplankton manual (pp. 191-196). Paris: UNESCO. 
Kerr, R. A. (1998). Models win big in forecasting El Niño. Science, 280, 522-523.

Kudela, R. M., \& Chávez, F. P. (2000). Modeling the impact of the 1991 El Niño on new production in Monterey Bay, California. Deep Sea Research II, 47, 1055-1076.

Lavaniegos, E. B., Gómez-Gutierrez, J. R., Lara-Lara, J. R., \& Hernández-Vázquez, S. (1998). Long-term changes in zooplankton volumes in the California Current System. The Baja California region. Marine Ecology Progress Series, 169, 55-64.

Lavaniegos, E. B., Jiménez-Perez, L. C., \& Gaxiola-Castro, G. (2002). Plankton response to El Niño 1997-1998 and La Niña 1999 in the sourthern region of the California Current. Progress in Oceanography, 54, 33-58.

Lavaniegos, E. B., \& Ohman, M. D. (2003). Long-term changes in pelagic tunicates of the California Current. Deep-Sea Research II, $50,2473-2498$.

Lavaniegos, E. B., Gaxiola-Castro, G., Jiménez-Pérez, L. C., González-Esparza, M. R., Baumgartner, T., \& García-Córdova, J. (2003). 1997-1998 El Niño effects on the pelagic ecosystem of the California Current off Baja California, México. Geofisica Internacional, 42, 483-494.

Lehodey, P. (2001). The pelagic ecosystem of the tropical Pacific Ocean: dynamic spatial modeling and biological consequences ENSO. Progress in Oceanography, 49, 439-468.

Madrid, J., \& Sánchez, P. (1997). Patterns in marine fish communities as shown by artisanal fisheries data on the shelf off Nexpa River, Michoacán, México. Fisheries Research, 33, 149-158.

Mackas, D. L., \& Galbraith, M. (2002). Zooplankton community composition along the inner portion of Line P during the $1997-1998$. Progress in Oceanography, 54, 423-437.

Mamayev, O. I. (1975). Temperature-salinity analysis of the word ocean waters. Amsterdam: Elsevier Scientific Publications Company.

McGowan, J. A. (1985). El Niño 1983 in the southern California Bight. In W. S. Wooster \& D. L. Fluharty (Eds.), El Niño North: El Niño effects in the eastern subartic Pacific Ocean (pp. 166-184). Seatle: Washington Sea Grand Program.

McPhaden, M. J. (1999). Genesis and evolution of the 1997-98 El Niño. Science, 283, 950-954.

Marinovic, B. B., Croll, D. A., Gong, N., Benson, S. R., \& Chavez, F. P. (2002). Effects of the 1997-1999 El Niño and La Niña events on zooplankton abundance and euphausiid comunity composition within the Monterey Bay coastal upwelling system. Progress in Oceanography, 54, 265-277.

Miller, C. B., Batchelder, H. P., Brodeur, R. D., \& Johnson, S. (1985). Response of the zooplankton and ichthyoplankton off Oregon to the El Niño event of 1983. In W. S. Wooster \& D. L. Fluharty (Eds.), El Niño North: El Niño effects in the eastern subartic Pacific Ocean (pp. 185-187). Washington Sea Grand Program.

Monthy Ocean Report. (1998). Climate and Marine Department, Japan Meteorological Agency (Vol. 67).

Moser, H. G., Charter, L. R., Smith, E. P., Ambrose, A. D., Charter, R. S., Meyer, C. A., et al. (1993). Distributional atlas of fish larvae and eggs in the California Current region: taxa with 1000 or more total larvae, 1951 through 1984. CalCOFI Atlas, 31 , 1-233.

Mullin, M. M. (1993). Webs and scales. Physical and ecological processes in marine fish recruitment (135pp). Seattle: Washington Sea Grant Program.

Mullin, M. M. (1995). The Californian El Niño of 1992 and the fall of Calanus. CalCOFI Report, 36, 175-178.

Mullin, M. M. (1998). Interannual and interdecadal variation in California Current zooplankton: Calanus in the late 1950s and early 1990s global change. Biology, 4, 115-119.

Mysak, L. K. (1986). El Niño interannual variability and fisheries in the northeast Pacific ocean. Canadian Journal Fisheries Aquatic Science, 43, 464- 497.

Norcross, B. L., \& Shaw, R. F. (1984). Oceanic and estuarine transport of fish egg and larvae: a review. Transactions of American Fisheries Society, 113, 153-165.

Paine, R. T. (1986). Benthic community-water column coupling during the 1982-1983 El Niño. Are community changes at high latitudes attributable to cause or coincidence?. Limnology and Oceanography, 31, 351-360.

Palomares-García, R., \& Gómez-Gutiérrez, J. (1996). Copepod community structure at Bahía Magdalena, México during El Niño 1983-84. Estuarine Coastal and Shelf Science, 43, 583-595.

Parrish, R. H., Nelson, C. S., \& Bakun, A. (1981). Transport mechanims and reproductive success of the fishes in the California Current. Biology Oceanography, 1, 175-203.

Pearcy, W. G., \& Schoener, A. (1987). Changes in the marine biota coincident with the 1982-1983 El Niño in the northeastern subarctic Pacific ocean. Journal Geophysical Research, 92, 14417-14428.

Peterson, W. T., \& Keister, J. E. (2003). Interannual variability in copepod community composition at a coastal station in the northern California Current: a multivariate approach. Deep Sea Research II, 50, 2499-2517.

Philander, S. G. (1998). Learning from El Niño. Weather, 53, 270-274.

Philander, S. G. (1999). A review of tropical ocean-atmosphere interactions. Tellus, 51, 71-90.

Roemmich, D., \& McGowan, J. (1995). Climatic warming and the decline of zooplankton in the California Current. Science, 267, 1324-1326.

Rodríguez-Graña, L., \& Castro, R. L. (2003). Ichthyoplankton distributions off the peninsula of Mejillones, Chile ( $\left.23^{\circ} \mathrm{S}, 71^{\circ} \mathrm{W}\right)$, under variable hydrographic conditions during the austral summer and winter of the 1997 El Niño. Hydrobiologia, 501, 59-73.

Roughgarden, J., Gaines, S., \& Possingham, H. (1988). Recruitment dynamics in complex life cycles. Science, 241, $1460-1466$. 
Sanchez-Velasco, L., Shirasago, B., Cisneros-Mata, M. A., \& Avalos-Garcia, C. (2000). Spatial distribution of small pelagic fish larvae in the Gulf of California and its relation to the El Niño 1997-1998. Journal of Plankton Research, 22, 1611-1618.

Sánchez-Velasco, L., Valdéz Holguín, J. E., Shirasago, B., Cisneros-Mata, M., \& Zárate, A. (2002). Changes in the spawning environment of Sardinops Caeruleus in the Gulf of California during El Niño 1997-1998. Estuarine Coastal and Shelf Science, 54, 207-217.

Smith, P. E., \& Moser, H. G. (2003). Long-term trends and variability in the larvae of Pacific sardine ans associated fish species of the California Current region. Deep-Sea Research II, 2519-2536.

Smith, P. E., Richardson, \& S. L. (1977). Standard techniques for pelagic fish egg and larvae surveyes. FAO Fisheries Technical paper (175p).

Tegner, M. J., \& Dayton, P. K. (1987). El Niño effects on Southern California kelp forest communities. Advances in Ecological Research, 17, 243-279.

Wolter, K., \& Timlin, M. S. (1993). Monitoring ENSO in COADS with a seasonally adjusted principal component index. In Proceedings of the 17th Climate Diagnostics Workshop, Norman, OK, NOAAIN MC/CAC, NSSL, Oklahoma Climatic Survey, CIMMS and the School of Meteorology (pp. 52-57). Univ. of Oklahoma.

Wolter, K., \& Timlin, M. S. (1998). Measuring the strength of ENSO - how does 1997/98 rank?. Weather, 53, 315-324.

Wyrtki, K. (1965). Surface currents of the Eastern Tropical Pacific Ocean. Inter-American Tropical Tuna Commission Bulletin IX(5), 271-304.

Zavala-García, F., \& Flores-Coto, C. (1994). Abundancia y distribución de larvas de Bregmacerotidae (Pises) en la Bahía de Campeche, México. Ciencias Marinas, 20, 219-241. 